\section{Digital literacy status of academic staff in the light of transformation in information and communication technologies}

\author{
Burçin $\mathrm{Işs}^{1}$ \\ Nurgül Özdemir ${ }^{2}$ \\ Sebahat Kuşlu ${ }^{3}$
}

\begin{abstract}
Objective: This study was planned to determine the digital literacy levels of faculty members and the factors affecting them in the light of the transformations in information and communication technologies and to create a resource for related studies.

Method: This cross-sectional and descriptive study was carried out in 2018 with 272 lecturers working at a state university. Personal Information Form and Digital Literacy Scale were used in data collection. Research data were analyzed in SPSS 22.0 package program. The data were analyzed using frequency, percentage, t test, Kolmogorov Smirnov, Mann-Whitney U and Kruskal Wallis test, and the results were evaluated at 95\% confidence interval and $\mathrm{p}$ $<0.05$ significance level.
\end{abstract}

Findings: The research results show that the digital literacy levels of the lecturers are very high, age, gender, academic title, study year affect the digital literacy level, the lecturers use
Özet

Amaç: $\mathrm{Bu}$ çalş̧ma, bilgi ve iletişim teknolojilerindeki dönüşümler 1şı̆̆ında öğretim elemanlarının dijital okuryazarlık düzeylerini ve etkileyen faktörleri belirlemek ve ilgili çalışmalara kaynak oluşturmak amacıyla planlanmıştır.

Yöntem: Kesitsel ve tanımlayıc1 olarak tasarlanmış bu çalıșma, 2018'de bir devlet üniversitesinde çalışan 272 öğretim elemanı ile gerçekleştirilmiştir. Veri toplamada, Kişisel Bilgi Formu ve Dijital Okuryazarlık Ölçeği kullanılmıştır. Araştırma verileri SPSS 22.0 paket programinda analiz edilmiştir. Veriler, frekans, yüzdelik, $t$ testi, Kolmogorov Smirnov, MannWhitney U ve Kruskal Wallis testi kullanilarak analiz edilmiş olup, sonuçlar \%95 güven aralığında, anlamllık $\quad \mathrm{p}<0.05$ düzeyinde değerlendirilmiştir.

Bulgular: Araştırma sonuçları, öğretim elemanlarının dijital okuryazarllk düzeylerinin çok yüksek olduğunu, yaş, cinsiyet, akademik ünvan, çalışma yllının dijital okuryazarlık

\footnotetext{
${ }^{1}$ Asst. Prof., Gaziantep Islamic Science and Technology University, Faculty of Health Sciences, Department of Nursing, burcev2201@yahoo.com. (D) Orcid ID: 0000-0002-5469-017X

${ }^{2}$ Asst. Prof., Gaziantep University, Faculty of Health Sciences, Department of Nursing, nuozdemir@hotmail.com (iD) Orcid ID: 0000-0002-9466-1357

${ }^{3}$ R.A., Gaziantep Islamic Science and Technology University, Faculty of Health Sciences, Department of Nursing, sebahat.kuslu@gibtu.edu.tr (DD) Orcid ID: 0000-0002-5861-4617
} 
Işık, B., Özdemir, N., \& Kușlu, S. (2021). Bilgi ve iletișim teknolojilerindeki dönüşümler 1șığında öğretim elemanlarının dijital okuryazarlık durumlar1. Journal of Human Sciences, 18(3), 374-389. doi:10.14687/jhs.v18i3.6131

digital technologies such as computers and projectors in educational activities to a large extent.

Conclusion: In line with these results, it should be ensured that education activities related to digital literacy skills should be organized within the scope of continuous education activities in higher education institutions, and especially and primarily, it should be ensured that academic staff and female instructors in the advanced age group participate in digital literacy training.

Keywords: Information and communication technologies, digital literacy, digital competencey, academic staff.

(Extended English summary is at the end of this document) düzeyini etkilediğini, öğretim elemanlarının bilgisayar ve projeksiyon gibi dijital teknolojileri eğitim etkinliklerinde büyük oranda kullandıklarını göstermektedir.

Sonuç: $\mathrm{Bu}$ sonuçlar doğrultusunda, Yükseköğretim kurumlarında sürekli eğitim etkinlikleri kapsaminda dijital okuryazarlık becerilerine ilişkin eğitim etkinlikleri düzenlenmesi, özellikle ve öncelikle, ileri yaş grubunda yer alan öğretim elemanlarının ve kadın öğretim elemanlarının dijital okuryazarlık eğitimlerine öncelikle katılmaları sağlanmalıdır.

Anahtar Kelimeler: Bilgi ve iletişim teknolojileri, dijital okuryazarlık, dijital yetkinlik, öğretim elemanı.

\section{GİRIş}

Küreselleşmeye ve bilgi üretimindeki artışa paralel olarak, özellikle yirminci yüzyllın sonlarında yaşanmaya başlayan hızlı teknolojik gelişim ve dönüşümler, var olan tüm kurum ve sistemleri karşı konulamaz bir değişim sürecine itmekte, her ülkenin, toplumun, kurumun, mesleğin ve bireyin geleceği üzerinde büyük bir etki oluşturmaktadır (Erişti, 2010; Ünal-Bozcan, 2010). Bütün bu etki ve dönüşümün neden olduğu tehditlere karşı koyabilmek, küreselleşen ve değişen bir dünyada yeni nesiller için güzel bir gelecek sağlamak adına eğitim sistemlerinin ve eğitimci yeterliklerinin değişmesi kaçınılmaz bir zorunluluk halini almıştır (Erişti, 2010). Uluslararası Eğitim Teknolojileri Kurumu (2008) yayınladığ1 raporda, yaşanan teknolojik dönüşümlere bağlı olarak eğitimcilerin;

- öğrencinin yaratıcılığını ve öğrenmesini arttırma,

- öğrencilerin dijital öğrenme deneyimi kazanmalarını sağlayacak ortamlar tasarlama ve geliştirme,

- dijital çağda yaşama, öğrenme ve çalışma,

- dijital çağdaki vatandaşlık rollerinin ve sorumluluklarının gelişmesinde yasal ve etik davranışlarıly model olma,

- yaşamboyu öğrenmeyi benimseme ve bu konuda öğrencilerine rol modeli olma vb.

yeterliklere sahip olmasının gerekliliğini belirtmiştir (ISTE, 2008). 2000'li yılların başlarında Avrupa Komisyonu da dijital okuryazarlık becerisini, yaşamboyu öğrenme yetkinliklerinden biri olarak belirlemiştir (Napal-Fraile et al., 2018, Compagno et al., 2016). Yaşamboyu öğrenmenin öne çıkması, bilgi ve iletişim teknolojilerinin gelişiminin her geçen gün daha fazla ivme kazanması, dijital okuryazarlığın önemini arttırmıştır (Özerbaş \& Kuralbayeva, 2018). Eshet-Alkalai (2004) dijital okuryazarllğı, “dijital çağda hayatta kalma becerisi” olarak tanımlamaktadır. Ng (2012)'ye göre, gelişen ve değişen teknolojilere uyum sağlama, dijital okuryazar olmanın göstergelerinden biridir. Dijital okuryazarlık, dijital boyutta doğru ve güvenilir bilgiye ulaşma, analizini yapma, değerlendirme, aktarma, bilinçli ve güvenli internet kullanımı, öğrenme-öğretme süreçlerinde bilgi ve iletişim teknolojilerini profesyonel düzeyde kullanma ve bu teknolojilerin öğrenci üzerindeki etkinliğinin farkında olma yeteneğini ifade etmektedir (Hamutoğlu ve ark., 2017; Selimi \& Üseini, 2019; Rokenes \& Krumsvik, 2016; Redecker, 2017; Benali et al., 2018). Martin (2008) ise, "dijital araçların 
Işık, B., Özdemir, N., \& Kușlu, S. (2021). Bilgi ve iletișim teknolojilerindeki dönüşümler 1șığında öğretim elemanlarının dijital okuryazarlık durumlar1. Journal of Human Sciences, 18(3), 374-389. doi:10.14687/jhs.v18i3.6131

bireysel ve mesleki yaşamda kullanılmasının önemine ilişkin bireylerin farkındalık kazanması, yeteneklerini ve tutumlarını geliştirmesi, dijital kaynaklara ulaşması, ulaştığı kaynakları analiz edebilmesi ve bu doğrultuda bilgi üretebilmesi olarak tanımlamış ve dijital okuryazarlı̆ğ; "dijital dönüşüm, dijital yeterlilik, dijital kullanım” olarak 3 aşamada ele almışıır. Bu bağlamda, dijital çağda öğrenen ve öğreten bireylerde bu becerileri geliştirmek 21. yüzyılda oldukça önemlidir. Çubukçu ve Bayzan (2013), dijital okuryazarlı̆̆ın bilinen okuryazarlıktan bile çok daha önemli hale gelmeye başladığını belirtmektedir. Dijital okuryazarlık geleneksel okuryazarlı̆̆ın bir alternatifi olmamakla birlikte, ona katkıda bulunan bir uzantısıdır ve günümüz dünyasında çalışma, öğrenme ve sosyalleşme için gereklidir (Churchill et al., 2008). Timur ve ark. (2014), ülkemizde dijital teknolojilerin bilinçli olarak kullanılmadığını, bu teknolojilere erişimin nicelik olarak her geçen gün arttığını, fakat nitelik bakımından yetersiz kaldığını, bu konuda eğitim kurumlarına, üniversitelere ve eğitimcilere çok fazla sorumluluk düştüğünü dile getirmişlerdir. Üniversiteler bilginin üretimi, korunması, yaygınlaştırılması ve uygulanması açısından toplumda önemli bir yere sahiptir. Toplumun yeni teknolojik gelişmelere uyum sağlayabilmesi, üniversitelerin, öğrenme-öğretme sürecinde dijital teknolojileri kullanımına ve geliştirmesine bağlıdır. Bu bağlamda, bireyler ve ülkeler arasındaki sayısal teknoloji temelindeki eşitsizliğin azaltılması için teknolojinin eğitim sistemi ile bütünleşmesi, bireylere teknolojiyi neden ve nasıl kullanılacağının öğretilmesi yaşamsal olup, bireylere, dijital yetkinliği kazandıracak olan eğitimcilerin de öncelikle kendilerinin bu yetkinliğe sahip olmas1 gerekmektedir (Ünal-Bozcan, 2010; Benali et al., 2018; Yapıc1 ve ark., 2010). Eğitimcilerin, yaşama göre kendilerini şekillendirmeleri, öğrenme-öğretme sürecini planlayabilmeleri, uygulayabilmeleri, değerlendirebilmeleri ve öğrenenlerin gereksinimlerine cevap verecek güçte olabilmeleri için, dijital okuryazarlık hakkındaki bilgi düzeyleri, dijital okuryazarlık düzeyleri ve becerileri ile dijital okuryazarlığa ilişkin görüşleri çok önemli bir sorundur (Özerbaş \& Kuralbayeva, 2018; Timur ve ark., 2014; Hakim, 2015). Eğitim sistemindeki dijitalleşme birey, toplum ve kamu otoriteleri açısından birçok verimliliği ve kolaylı̆̆ da beraberinde getirmektedir (Parlak, 2017). Son yıllarda ortaya çıkan ve tüm dünyayı etkisi altına alan salgın süreci ile beraber öğretmenlerin çevrimiçi ortamlara yönelik bilgi, beceri ve deneyimleri de önem kazanmaya başlamıştır (Ak ve ark., 2021). Eğitim süreçlerinde dijital teknolojilerin verimli ve etkin bir şekilde kullanımının, öğrenenleri bireysel ve etkin bir biçimde öğrenmeye teşvik ettiği, öğrenenlerin motivasyonunu arttırdığ1, düşüncelerinde bağımsız olmalarını sağladığı ve böylece öğrenme-öğretme sürecinde daha etkin olmalarını sağladığı belirtilmektedir (Ünal-Bozcan, 2010; Benali et al., 2018; Yapıc1 ve ark., 2010; Güçlü ve ark., 2010).

Sonuç olarak, Friedrich Nietzsche'nin "Derisini değiștirmeyi bilmeyen y1lan ölür" sözünden yola çıkarak, eğitimcilerin, bilgi ve iletişim teknolojilerindeki gelişim ve değişim döngüsü karşısında, mesleklerinin gereği olan görev ve sorumlulukları gerçekleştirmek için mesleki yeterlik ve niteliklerini sürekli geliştirme zorunluluğu ile yüzyüze oldukları kaçınılmaz bir gerçektir. Sözü edilenler ışığında bu araştırma, bilgi ve iletişim teknolojilerindeki dönüşümler sşığında öğretim elemanlarının dijital okuryazarlık düzeylerini ve etkileyen faktörleri belirlemek ve ilgili çalısmalara kaynak oluşturmak amacıyla planlanmıştır.

\section{YÖNTEM}

Araştırmanın Amacı ve Tipi: Araştırma, bilgi ve iletişim teknolojilerindeki dönüşümler ışığında öğretim elemanlarının dijital okuryazarlık düzeylerini ve etkileyen faktörleri belirlemek, ilgili çalışmalara kaynak oluşturmak amacıyla tanımlayıcı ve kesitsel tipte planlanmıştır.

Araştırmanın Evreni ve Örneklemi: Araştırma 03.09.-28.12.2018 tarihleri arasında gerçekleştirilmiştir. Araştırmanın evrenini, Gaziantep Üniversitesi bünyesinde yer alan 14 fakülte (Tip, Mühendislik, Diş Hekimliği, Sağlık Bilimleri, Mimarlık, Eğitim, Güzel Sanatlar, Hukuk, FenEdebiyat, Havacilık ve Uzay Bilimleri, İlahiyat, İletişim, İktisadi ve İdari Bilimler, Turizm), 4 yüksekokul (Beden Eğitimi ve Spor, Sivil Havacıllk, Yabanc1 Diller, Türk Musikisi Devlet Konservatuarı) ve 4 meslek yüksekokulu (Turizm ve Otelcilik, Sağlık Hizmetleri, Sosyal Bilimler, Teknik Bilimler) bölümlerinde çalışan 1344 öğretim elemanı oluşturmaktadır. Örneklem büyüklüğü 
Işık, B., Özdemir, N., \& Kușlu, S. (2021). Bilgi ve iletișim teknolojilerindeki dönüşümler 1șığında öğretim elemanlarının dijital okuryazarlık durumlar1. Journal of Human Sciences, 18(3), 374-389. doi:10.14687/jhs.v18i3.6131

basit rastgele örnekleme yöntemi ile belirlenmiş olup, Sağlık Bilimleri Fakültesi, Tıp Fakültesi, Eğitim Fakültesi, Fen-Edebiyat Fakültesi, Mühendislik Fakültesi, Sağllk Hizmetleri Meslek Yüksekokulu, Sosyal Bilimler Meslek Yüksekokulu, ve Teknik Bilimler Meslek Yüksekokulu’nda çalışan, araştırmaya katılmaya istekli olan 272 öğretim elemanı ile gerçekleştirilmiştir.

Veri Toplama Araçları: Veri toplama aracı olarak, araştırmacılar tarafindan literatür doğrultusunda hazırlanan Kişisel Bilgi Formu ve Dijital Okuryazarlık Ölçeği kullanılmıştır.

Kişisel Bilgi Formu : Literatür temelinde araştırmacıların hazırladığı, cinsiyet, yaş, bölüm, ünvan, internete bağlanmak için kullanılan teknolojiler, eğitim etkinliklerinde kullanılan araçgereçler, kendine ait bir web sitesine sahip olma durumu, günde kaç saat internet kullanıldı̆̆1 ve internetin hangi amaçlarla kullanıldığı vb. konuları içeren 16 sorudan oluşmaktadır.

Dijital Okuryazarlık Ölçeği (DOYÖ): Acar tarafindan 2015 yllında geliştirilen DOYÖ beş alt boyuttan ve 41 sorudan oluşmaktadır. Çalışmamızda, ölçeğin bütünü için .980 , güvenli katılım alt ölçeği için .928, farkındalık alt ölçeği için .968, temel araç ve ortam bilgisi alt ölçeği için .899 , dijital kimlik yönetimi alt ölçeği için .908, bağlamsal kullanım alt ölçeği için .958 olarak cronbach alpha değerleri bulunmuştur. Ölçekten alınabilecek puanlar ise; Farkındalık alt ölçeğinden en yüksek 85 (17x5) en düşük 17 (17x1) puan; bağlamsal kullanım alt ölçeğinden en yüksek 45 (9x5) en düşük 9 (9x1) puan; güvenli katulım alt ölçeğinden en yüksek $30(6 \times 5)$ en düşük $6(6 \times 1)$ puan; dijital kimlik yönetimi alt ölçeğinden en yüksek 20 (4x5) en düşük 4 (4x1) puan; temel araç ve ortam bilgisi alt ölçeğinden en yüksek $25(5 \times 5)$ en düşük $5(5 \times 1)$ puan ve ölçeğin bütününden en yüksek 205 (41x5) en düşük ise 41 (41x1) puan olarak belirlenmiştir (Acar, 2015).

Veri Analizi: Araştırma verileri SPSS 22.0 paket programında analiz edilmiştir. Veriler, frekans, yüzdelik, t testi, Kolmogorov Smirnov, Mann-Whitney U ve Kruskal Wallis testi kullanılarak analiz edilmiş olup, sonuçlar \%95 güven aralığında, anlamllık $\mathrm{p}<0.05$ düzeyinde değerlendirilmiştir.

Araştırmanın Etik Yönü: Araştırma sürecinin başında Gaziantep Üniversitesi Klinik Araştırmaları Etik Kurulu'ndan (Karar No:2018/168) ve çalışmanın yapılacağ1 Gaziantep Üniversitesi Rektörlüğü'nden kurum izni alınmış olup, araştırmaya dahil edilecek bireylere araştırma kapsamında bilgilendirme yapılmış ve araştırma sürecine katılmayı kabul eden bireylerden bilgilendirilmiş sözlü ve yazılı onam alınmıştır. Ayrıca ölçek sahibinden gerekli izin alınmıştır.

Araştırmanın Sınırlılıkları: Araştırma, bir devlet üniversitedeki öğretim elemanları ile sınırlıdır. Farklı bölgelerdeki yükseköğretim kurumlarında görev yapan öğretim elemanları ile ileriye dönük, nitel araştırmaların yapılması bulguların genellenebilirliği açısından önerilir.

\section{BULGULAR}

Katilımcıların \%36,76's1 (n:100) meslek yüksekokullarından, \%13,2'si (n:36) Fen-Edebiyat Fakültesinden, \%11’i (n:30) Sağllk Bilimleri Fakültesinden, \%12,1’i (n:33) Mühendislik Fakültesi, $\% 18,3$ 'ü (n:50) Tip Fakültesinden ve \%8,4’ü (n:23) Eğitim Fakültesindendir. Araştırmaya katılanların yaş ortalaması 36,05+9,52 iken, \%52,6'sı erkek, \%36,8’i öğretim görevlisi, \%29’u ise 12 ve üzeri yıldan beri öğretim elemanı olarak çalışmakta olduğunu ve \%100’ü interneti kullandığını ifade etmiştir. Çalışmaya katılan öğretim elemanlarının \% 90.8’i internete bağlanmak için cep telefonu, \%85,7'si dizüstü bilgisayar kullandığını ifade etmiştir.

Tablo 1. Öğretim Elemanlarının Dijital Okuryazarlık Ölçeği Alt Boyutlarından Aldıkları paun Ortalamaları ve Standart Sapmaları

\begin{tabular}{llll}
\hline Dijital Okuryazarlık Ölçeği Alt Boyutları & Madde Sayısı & $\overline{\mathbf{x}}$ & SS \\
\hline Farkındalık & 17 & 71.51 & 11.91 \\
\hline Bağlamsal Kullanım & 9 & 38.57 & 6.94 \\
\hline Güvenli Katılım & 6 & 23.38 & 5.26 \\
\hline Dijital Kimlik & 4 & 15.55 & 3.25 \\
\hline Temel Araç ve Ortam Bilgisi & 5 & 19.37 & 4.37 \\
\hline Genel Ortalama & 41 & 169.05 & 28.71 \\
\hline
\end{tabular}


Işık, B., Özdemir, N., \& Kuşlu, S. (2021). Bilgi ve iletişim teknolojilerindeki dönüşümler 1şığında öğretim elemanlarının dijital okuryazarlık durumlar1. Journal of Human Sciences, 18(3), 374-389. doi:10.14687/jhs.v18i3.6131

Öğretim elemanlarının DOYÖ toplam puan ortalamalarının 169,05 $\pm 28,71$, Farkındalık alt

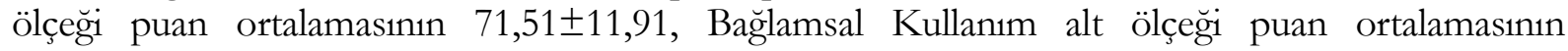

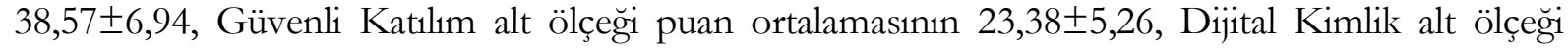

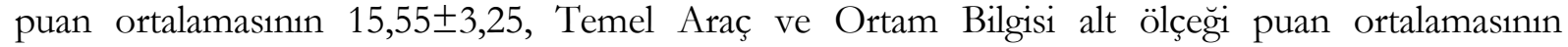

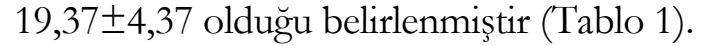

Tablo 2. Öğretim Elemanlarının Sosyo-Demografik Özelliklerine Göre Dijital Okuryazarlık Ölçeği ve Alt Boyutlarından Aldıkları Puan Ortalamaları ve Karşılaştırılması

\begin{tabular}{|c|c|c|c|c|c|c|c|c|}
\hline & & n (\%) & Farkındalık & $\begin{array}{l}\text { Bağlamsal } \\
\text { Kullanım }\end{array}$ & $\begin{array}{l}\text { Güvenli } \\
\text { Katılım }\end{array}$ & $\begin{array}{l}\text { Dijital } \\
\text { Kimlik }\end{array}$ & $\begin{array}{l}\text { Temel Araç } \\
\text { ve Ortam } \\
\text { Bilgisi }\end{array}$ & Toplam \\
\hline \multirow[t]{6}{*}{ Yaş } & $22-27$ yaş & $77(28.3)$ & $74.16 \pm 10.58$ & $40.28 \pm 5.76$ & $24.83 \pm 4.74$ & $16.16 \pm 3.22$ & $20.05 \pm 4.16$ & $176.42 \pm 25.24$ \\
\hline & $28-33$ yaş & $26(9.6)$ & $72.15 \pm 10.61$ & $38.23 \pm 7.08$ & $24.34 \pm 5.21$ & $15.96 \pm 3.31$ & $20.07 \pm 4.95$ & $171.26 \pm 28.59$ \\
\hline & 34-39 yaş & $77(28.3)$ & $72.05 \pm 11.51$ & $39.31 \pm 6.64$ & $23.05 \pm 5.15$ & $15.41 \pm 3.24$ & $19.36 \pm 4.62$ & $169.85 \pm 27.44$ \\
\hline & $40-45$ yaş & $54(19.9)$ & $70.18 \pm 12.58$ & $37.31 \pm 7.68$ & $22.48 \pm 5.58$ & $15.31 \pm 3.23$ & $18.98 \pm 4.26$ & $164.79 \pm 30.51$ \\
\hline & $46-51$ yaş & $16(5.9)$ & $70.37 \pm 13.63$ & $36.75 \pm 8.04$ & $23.5 \pm 5.41$ & $15.31 \pm 3.30$ & $18.93 \pm 4.26$ & $165.37 \pm 32.16$ \\
\hline & 52-üstü yaş & $22(8.1)$ & $63.72 \pm 13.51$ & $34.81 \pm 7.22$ & $20.45 \pm 5.31$ & $14.13 \pm 3.04$ & $17.54 \pm 3.54$ & $150.90 \pm 30.51$ \\
\hline \multirow{2}{*}{\multicolumn{2}{|c|}{ Test ve Anlamlılık }} & & F: 2.95 & F: 3.10 & F: 3.20 & F:1.59 & $\mathrm{F}: 1.40$ & $\mathrm{~F}: 3.23$ \\
\hline & & & $\mathrm{p}: 0.01$ & $\mathrm{p}: 0.01$ & p: 0.008 & p:0.16 & $\mathrm{p}: 0.22$ & $\mathrm{p}: 0.007$ \\
\hline \multirow[t]{2}{*}{ Cinsiyet } & Kadın & $\begin{array}{l}129 \\
(47.4)\end{array}$ & $71.46 \pm 11.97$ & $38.07 \pm 7.13$ & $23.43 \pm 5.06$ & $15.60 \pm 3.25$ & $18.78 \pm 4.36$ & $168.17 \pm 28.76$ \\
\hline & Erkek & $\begin{array}{l}143 \\
(52.6) \\
\end{array}$ & $71.56 \pm 11.89$ & $39.02 \pm 6.75$ & $23.33 \pm 5.46$ & $15.50 \pm 3.26$ & $19.91 \pm 4.33$ & $169.84 \pm 28.73$ \\
\hline \multirow{2}{*}{\multicolumn{2}{|c|}{ Test ve Anlamlilik }} & & $\mathrm{t}:-0.07$ & $\mathrm{t}:-1.12$ & $\mathrm{t}: 0.15$ & $\mathrm{t}: 0.25$ & $\mathrm{t}:-2.14$ & $\mathrm{t}:-0.48$ \\
\hline & & & $\mathrm{p}: 0.94$ & $\mathrm{p}: 0.26$ & p: 0.87 & $\mathrm{p}: 0.79$ & $\mathrm{p}: 0.03$ & p: 0.63 \\
\hline \multirow[t]{7}{*}{ Ünvan } & Profesör & $10(3.7)$ & $74.50 \pm 6.81$ & $41.20 \pm 3.61$ & $23.20 \pm 3.76$ & $15.50 \pm 2.79$ & $19.50 \pm 3.20$ & $173.70 \pm 15.36$ \\
\hline & Doçent & $18(6.6)$ & $71.0 \pm 9.08$ & $39.72 \pm 4.59$ & $23.05 \pm 4.70$ & $15.0 \pm 3.19$ & $19.33 \pm 3.41$ & $169.0 \pm 21.76$ \\
\hline & $\begin{array}{l}\text { Dr.Öğr. } \\
\text { Üyesi }\end{array}$ & $55(20.2)$ & $71.69 \pm 10.34$ & $39.27 \pm 6.38$ & $22.16 \pm 5.17$ & $15.0 \pm 3.0$ & $18.98 \pm 4.51$ & $168.12 \pm 24.81$ \\
\hline & Arş.Gör. & $54(19.9)$ & $74.74 \pm 9.58$ & $40.81 \pm 4.95$ & $24.87 \pm 4.71$ & $16.14 \pm 3.04$ & $20.01 \pm 3.84$ & $177.48 \pm 22.64$ \\
\hline & Öğr.Gör. & $\begin{array}{l}100 \\
(36.8) \\
\end{array}$ & $68.75 \pm 13.71$ & $36.16 \pm 8.08$ & $22.84 \pm 5.60$ & $15.25 \pm 3.44$ & $18.86 \pm 4.80$ & $162.22 \pm 33.28$ \\
\hline & Okutman & $18(6.6)$ & $78.50 \pm 7.50$ & $41.72 \pm 4.05$ & $26.11 \pm 3.69$ & $17.44 \pm 2.74$ & $21.38 \pm 3.85$ & $185.83 \pm 19.26$ \\
\hline & Diğer & $17(6.3)$ & $68.41 \pm 15.70$ & $37.29 \pm 8.45$ & $23.35 \pm 6.52$ & $15.82 \pm 3.74$ & $19.52 \pm 4.65$ & $165.0 \pm 37.67$ \\
\hline \multicolumn{2}{|c|}{ Test ve Anlamlılık } & & $\begin{array}{l}\text { F: } 3.02 \\
\text { p: } \mathbf{0 . 0 0 7}\end{array}$ & $\begin{array}{l}\text { F: } 4.38 \\
\text { p: } \mathbf{0 . 0 0}\end{array}$ & $\begin{array}{l}\text { F: } 2.26 \\
\text { p: } \mathbf{0 . 0 3}\end{array}$ & $\begin{array}{l}\text { F: } 1.86 \\
\text { p: } 0.08\end{array}$ & $\begin{array}{l}\text { F: } 1.14 \\
\text { p: } 0.33\end{array}$ & F: 2.97 p: $\mathbf{0 . 0 0 8}$ \\
\hline \multirow{5}{*}{$\begin{array}{l}\text { Öğretim } \\
\text { elemanı } \\
\text { olarak } \\
\text { çalışma yllı }\end{array}$} & 1 ay-2 yil & $75(27.6)$ & $73.97 \pm 9.69$ & $39.85 \pm 5.26$ & $23.86 \pm 4.70$ & $15.74 \pm 2.77$ & $19.25 \pm 4.16$ & $173.85 \pm 22.21$ \\
\hline & $3-5$ yll & $52(19.1)$ & $73.86 \pm 10.68$ & $40.26 \pm 5.81$ & $24.25 \pm 5.11$ & $16.05 \pm 3.29$ & $20.55 \pm 4.22$ & $175.57 \pm 25.73$ \\
\hline & $6-8 \mathrm{yll}$ & $47(17.3)$ & $69.85 \pm 10.66$ & $38.31 \pm 5.92$ & $23.40 \pm 4.37$ & $15.63 \pm 2.87$ & $19.53 \pm 3.43$ & $167.12 \pm 25.08$ \\
\hline & $9-11$ yll & $19(7.0)$ & $66.36 \pm 13.09$ & $34.73 \pm 8.39$ & $22.26 \pm 6.03$ & $14.57 \pm 3.90$ & $18.89 \pm 5.08$ & $157.42 \pm 33.71$ \\
\hline & $\begin{array}{ll}12 \text { yll ve } \\
\text { üstü }\end{array}$ & $79(29.0)$ & $69.87 \pm 14.21$ & $37.31 \pm 8.56$ & $22.60 \pm 6.08$ & $15.21 \pm 3.65$ & $18.74 \pm 4.90$ & $164.13 \pm 34.91$ \\
\hline \multicolumn{2}{|c|}{ Test ve Anlamlılık } & & $\begin{array}{l}\text { F: } 2.87 \\
\text { p: } \mathbf{0 . 0 2}\end{array}$ & $\begin{array}{l}\text { F: } 3.66 \\
\text { p: } \mathbf{0 . 0 0 6}\end{array}$ & $\begin{array}{l}\text { F: } 1.15 \\
\text { p: } 0.33\end{array}$ & $\begin{array}{l}\text { F: } 1.02 \\
\text { p: } 0.39\end{array}$ & $\begin{array}{l}\text { F: } 1.45 \\
\text { p: } 0.21\end{array}$ & $\begin{array}{l}\text { F: } 2.67 \\
\text { p: } 0.03\end{array}$ \\
\hline $\begin{array}{l}\text { Internet } \\
\text { Kullanim } \\
\text { durumu }\end{array}$ & Evet & $\begin{array}{l}272 \\
(100)\end{array}$ & $71.51 \pm 11.91$ & $38.57 \pm 6.94$ & $23.38 \pm 5.26$ & $15.55 \pm 3.25$ & $19.37 \pm 4.37$ & $169.05 \pm 28.71$ \\
\hline
\end{tabular}

Öğretim elemanlarının yaş grubu ile DOYÖ’nün Farkındalık, Bağlamsal Kullanım, Güvenli Katılım alt boyutları ile toplam puan ortalamaları arasında istatistiki açıdan anlamlı fark olduğu $(\mathrm{p}<0.05)$, ve bu farkın 22-27 yaş grubu lehine olduğu saptanmıştır. Öğretim elemanlarının akademik ünvanı ile DOYÖ’nün Farkındalık, Bağlamsal Kullanım, Güvenli Katılım alt boyutları ile toplam puan ortalamaları arasında istatistiki açıdan anlamlı fark olduğu $(p<0.05)$, ve bu farkın okutman ünvanına sahip öğretim elemanlarının lehine olduğu belirlenmiştir. Öğretim elemanlarının, öğretim elemanı olarak çalıştıkları süre ile DOYÖ'nün Farkındalık, Bağlamsal Kullanım alt boyutları ile toplam puan ortalamaları arasında istatistiki açıdan anlamlı fark olduğu $(\mathrm{p}<0.05)$ saptanmıştır. Farkındalık alt boyutundaki farkın 1 ay-2 yıl gibi bir süreyle çalışan öğretim elemanlarının lehine olduğu, Bağlamsal Kullanım ve Toplam boyutundaki farkın 3-5 y1l süreyle çalışan öğretim elemanlarının lehine olduğu belirlenmiştir (Tablo 2). 
Işık, B., Özdemir, N., \& Kuşlu, S. (2021). Bilgi ve iletişim teknolojilerindeki dönüşümler ışığında öğretim elemanlarının dijital okuryazarlık durumlar1. Journal of Human Sciences, 18(3), 374-389. doi:10.14687/jhs.v18i3.6131

Tablo 3. Öğretim Elemanlarının Eğitim Etkinliklerinde Kullandıkları Teknolojik Araç-Gereçlere Göre Dijital Okuryazarlık Ölçeği ve Alt Boyutlarından Aldıkları Puan Ortalamaları ve

Karşılaştırilması

\begin{tabular}{|c|c|c|c|c|c|c|c|c|}
\hline \multicolumn{2}{|c|}{$\begin{array}{l}\text { Ĕgitim etkinliklerinde } \\
\text { kullanılan teknolojik } \\
\text { araç-gereçler }\end{array}$} & n (\%) & Farkındalık & $\begin{array}{l}\text { Bağlamsal } \\
\text { Kullanım }\end{array}$ & $\begin{array}{l}\text { Güvenli } \\
\text { Katılım }\end{array}$ & $\begin{array}{l}\text { Dijital } \\
\text { Kimlik }\end{array}$ & $\begin{array}{l}\text { Temel } \\
\text { Araç } \\
\text { Ortam } \\
\text { Bilgisi }\end{array}$ & Toplam \\
\hline \multirow[t]{2}{*}{$\begin{array}{l}\text { Tepegöz- } \\
\text { Saydam }\end{array}$} & Evet & $\begin{array}{l}37 \\
(13.6)\end{array}$ & $74.18 \pm 10.18$ & $39.51 \pm 6.20$ & $24.54 \pm 4.23$ & $16.29 \pm 2.49$ & $19.78 \pm 4.33$ & $174.75 \pm 24.20$ \\
\hline & Hayır & $\begin{array}{l}235 \\
(86.4)\end{array}$ & $71.09 \pm 12.12$ & $38.42 \pm 7.05$ & $23.20 \pm 5.39$ & $15.43 \pm 3.34$ & $19.31 \pm 4.38$ & $168.15 \pm 29.30$ \\
\hline \multicolumn{2}{|c|}{ Test ve Anlamlilık } & & $\mathrm{t}: 1.47 \mathrm{p}: 0.14$ & $\begin{array}{l}\text { t:0.88 } \\
\text { p:0.37 }\end{array}$ & $\mathrm{t}: 1.44 \mathrm{p}: 0.15$ & $\mathrm{t}: 1.50 \mathrm{p}: 0.13$ & $\begin{array}{l}\mathrm{t}: 0.60 \\
\mathrm{p}: 0.54\end{array}$ & $\mathrm{t}: 1.30 \mathrm{p}: 0.19$ \\
\hline \multirow[t]{2}{*}{$\begin{array}{l}\text { Slayt } \\
\text { Makinesi }\end{array}$} & Evet & $\begin{array}{l}156 \\
(57.4)\end{array}$ & $73.88 \pm 9.92$ & $40.48 \pm 5.27$ & $23.94 \pm 4.98$ & $15.86 \pm 3.08$ & $20.04 \pm 4.01$ & $175.0 \pm 23.49$ \\
\hline & Hayır & $\begin{array}{l}116 \\
(42.6)\end{array}$ & $68.33 \pm 13.56$ & $36.0 \pm 8.02$ & $22.62 \pm 5.56$ & $15.12 \pm 3.42$ & $18.48 \pm 4.68$ & $161.04 \pm 32.94$ \\
\hline \multicolumn{2}{|c|}{ Test ve Anlamlilık } & & $\mathrm{t}: 3.72 \mathrm{p}: \mathbf{0 . 0 0}$ & $\begin{array}{l}\mathrm{t}: 5.23 \\
\mathrm{p}: 0.00\end{array}$ & $\begin{array}{l}\mathrm{t}: 2.06 \\
\mathrm{p}: 0.04\end{array}$ & $\mathrm{t}: 1.85 \mathrm{p}: 0.06$ & $\begin{array}{l}\mathrm{t}: 2.95 \\
\mathrm{p}: \mathbf{0 . 0 0 3}\end{array}$ & t:3.88 p:0.00 \\
\hline \multirow[t]{2}{*}{$\begin{array}{l}\text { Televizyon- } \\
\text { Video }\end{array}$} & Evet & $\begin{array}{l}71 \\
(26.1) \\
\end{array}$ & $73.98 \pm 9.85$ & $40.08 \pm 5.82$ & $24.56 \pm 4.25$ & $16.29 \pm 2.96$ & $20.09 \pm 4.06$ & $175.45 \pm 23.71$ \\
\hline & Hayır & $\begin{array}{l}201 \\
(73.9) \\
\end{array}$ & $70.64 \pm 12.46$ & $38.03 \pm 7.23$ & $22.96 \pm 5.53$ & $15.28 \pm 3.31$ & $19.12 \pm 4.46$ & $166.79 \pm 30.0$ \\
\hline \multicolumn{2}{|c|}{ Test ve Anlamlılık } & & $\mathrm{t}: 2.04 \mathrm{p}: \mathbf{0 . 0 4}$ & $\begin{array}{l}\mathrm{t}: 2.38 \\
\mathrm{p}: \mathbf{0 . 0 1}\end{array}$ & $\mathrm{t}: 2.50 \mathrm{p}: \mathbf{0 . 0 1}$ & $\begin{array}{l}\mathrm{t}: 2.26 \\
\mathrm{p}: \mathbf{0 . 0 2}\end{array}$ & $\begin{array}{l}\mathrm{t}: 1.61 \\
\mathrm{p}: 0.10\end{array}$ & $\mathrm{t}: 2.45$ p:0.01 \\
\hline \multirow[t]{2}{*}{ Filmler } & Evet & $\begin{array}{l}103 \\
(37.9) \\
\end{array}$ & $73.61 \pm 10.89$ & $39.90 \pm 6.16$ & $25.04 \pm 4.49$ & $16.22 \pm 2.78$ & $20.69 \pm 4.0$ & $175.85 \pm 25.98$ \\
\hline & Hayır & $\begin{array}{l}169 \\
(62.1)\end{array}$ & $70.24 \pm 12.34$ & $37.76 \pm 7.27$ & $22.36 \pm 5.45$ & $15.14 \pm 3.45$ & $18.57 \pm 4.40$ & $164.90 \pm 29.56$ \\
\hline \multicolumn{2}{|c|}{ Test ve Anlamlılık } & & $\mathrm{t}: 2.28 \mathrm{p}: \mathbf{0 . 0 2}$ & $\begin{array}{l}\mathrm{t}: 2.48 \\
\mathrm{p}: \mathbf{0 . 0 1}\end{array}$ & $\begin{array}{l}\mathrm{t}: 4.39 \\
\mathrm{p}: \mathbf{0 . 0 0}\end{array}$ & $\begin{array}{l}\mathrm{t}: 2.83 \\
\mathrm{p}: \mathbf{0 . 0 0 5}\end{array}$ & $\begin{array}{l}\text { t:3.99 } \\
\text { p:0.00 }\end{array}$ & $\begin{array}{l}\text { t:3.09 } \\
\text { p:0.002 }\end{array}$ \\
\hline \multirow[t]{2}{*}{ Bilgisayar } & Evet & $\begin{array}{l}246 \\
(90.4) \\
\end{array}$ & $71.80 \pm 11.81$ & $38.95 \pm 6.62$ & $23.65 \pm 5.13$ & $15.67 \pm 3.17$ & $19.65 \pm 4.19$ & $170.37 \pm 27.87$ \\
\hline & Hayır & $26(9.6)$ & $68.84 \pm 12.67$ & $34.96 \pm 8.79$ & $20.76 \pm 5.91$ & $14.34 \pm 3.77$ & $16.73 \pm 5.22$ & $156.50 \pm 33.76$ \\
\hline \multicolumn{2}{|c|}{ Test ve Anlamlılık } & & $\mathrm{t}: 1.20 \mathrm{p}: 0.23$ & $\begin{array}{l}\mathrm{t}: 2.24 \\
\mathrm{p}: \mathbf{0 . 0 3}\end{array}$ & $\begin{array}{l}\mathrm{t}: 2.69 \\
\mathrm{p}: \mathbf{0 . 0 0 8}\end{array}$ & $\begin{array}{l}\mathrm{t}: 1.99 \\
\mathrm{p}: \mathbf{0 . 0 4}\end{array}$ & $\begin{array}{l}\mathrm{t}: 3.30 \\
\mathrm{p}: 0.001\end{array}$ & $\mathrm{t}: 2.36 \mathbf{p}: \mathbf{0 . 0 1}$ \\
\hline \multirow[t]{2}{*}{ Projeksiyon } & Evet & $\begin{array}{l}123 \\
(45.2) \\
\end{array}$ & $73.96 \pm 9.12$ & $40.73 \pm 4.70$ & $23.73 \pm 4.94$ & $15.56 \pm 3.20$ & $19.81 \pm 4.00$ & $174.73 \pm 21.53$ \\
\hline & Hayır & $\begin{array}{l}149 \\
(54.8) \\
\end{array}$ & $69.49 \pm 13.49$ & $36.79 \pm 7.93$ & $23.09 \pm 5.51$ & $15.54 \pm 3.30$ & $19.02 \pm 4.64$ & $164.35 \pm 32.83$ \\
\hline \multicolumn{2}{|c|}{ Test ve Anlamlılık } & & t:3.24 p:0.001 & $\begin{array}{l}\text { t:5.07 } \\
\text { p:0.000 }\end{array}$ & t:0.99 p:0.32 & t:0.04 p:0.96 & $\begin{array}{l}\mathrm{t}: 1.49 \\
\mathrm{p}: 0.13 \\
\end{array}$ & $\begin{array}{l}\mathrm{t}: 3.13 \\
\mathrm{p}: 0.002 \\
\end{array}$ \\
\hline Kağıt Tahtası & $\begin{array}{l}\text { Evet } \\
\text { Hayır }\end{array}$ & $\begin{array}{l}16(5.9) \\
256 \\
(94.1)\end{array}$ & $\begin{array}{l}73.0 \pm 12.01 \\
71.42 \pm 11.92\end{array}$ & $\begin{array}{l}38.75 \pm 6.55 \\
38.56 \pm 6.97\end{array}$ & $\frac{24.5 \pm 4.99}{23.31 \pm 5.28}$ & $\begin{array}{l}15.81 \pm 3.46 \\
15.53 \pm 3.24\end{array}$ & $\begin{array}{l}\frac{20.31 \pm 4.85}{19.32 \pm 4.34} \\
\end{array}$ & $\frac{172.50 \pm 29.75}{168.83 \pm 28.69}$ \\
\hline \multicolumn{2}{|c|}{ Test ve Anlamlılık } & & t:0.51 p:0.60 & $\begin{array}{l}\mathrm{t}: 0.10 \\
\mathrm{p}: 0.91\end{array}$ & t:0.87 p:0.38 & t:0.33 p:0.74 & $\begin{array}{l}\text { t:0.88 } \\
\mathrm{p}: 0.38\end{array}$ & t:0.49 p:0.62 \\
\hline \multirow[t]{2}{*}{ Yaz1 Tahtası } & Evet & $\begin{array}{l}176 \\
(64.7) \\
\end{array}$ & $71.65 \pm 11.78$ & $38.57 .242 \pm$ & $23.53 \pm 5.22$ & $15.53 \pm 3.31$ & $19.48 \pm 4.49$ & $169.28 \pm 29.22$ \\
\hline & Hayır & $\begin{array}{l}96 \\
(35.3)\end{array}$ & $71.27 \pm 12.19$ & $38.66 \pm 6.39$ & $23.10 \pm 5.36$ & $15.58 \pm 3.15$ & $19.18 \pm 4.16$ & $168.62 \pm 27.89$ \\
\hline \multicolumn{2}{|c|}{ Test ve Anlamlılik } & & t:0.25 p:0.80 & $\begin{array}{l}\text { t:-0.16 } \\
\mathrm{p}: 0.87\end{array}$ & $\mathrm{t}: 0.64$ p:0.52 & $\begin{array}{l}\text { t:-0.11 } \\
\mathrm{p}: 0.90\end{array}$ & $\begin{array}{l}\mathrm{t}: 0.53 \\
\mathrm{p}: 0.59\end{array}$ & t:0.18 p:0.85 \\
\hline \multirow[t]{2}{*}{ Ak1ll1 tahta } & Evet & $12(4.4)$ & $75.66 \pm 13.05$ & $41.16 \pm 6.82$ & $26.0 \pm 5.06$ & $16.33 \pm 3.44$ & $21.83 \pm 4.68$ & $180.91 \pm 31.70$ \\
\hline & Hayır & $\begin{array}{l}260 \\
(95.6)\end{array}$ & $71.32 \pm 11.84$ & $38.45 \pm 6.93$ & $23.26 \pm 5.25$ & $15.51 \pm 3.24$ & $19.26 \pm 4.33$ & $168.50 \pm 28.51$ \\
\hline \multicolumn{3}{|c|}{ Test ve Anlamlilık } & $\mathrm{t}: 1.23$ p:0.21 & $\begin{array}{l}\mathrm{t}: 1.32 \\
\mathrm{p}: 0.18\end{array}$ & $\mathrm{t}: 1.76 \mathrm{p}: 0.07$ & t:0.85 p:0.39 & $\begin{array}{l}\mathrm{t}: 1.99 \\
\mathrm{p}: \mathbf{0 . 0 4}\end{array}$ & $\mathrm{t}: 1.46$ p:0.14 \\
\hline
\end{tabular}

Katılımciların \% 90,4’ünün eğitim etkinliklerinde bilgisayar, \%64,7'sinin yazı tahtas1 kullandığı belirlenmiştir (Tablo 3). 
Işık, B., Özdemir, N., \& Kuşlu, S. (2021). Bilgi ve iletişim teknolojilerindeki dönüşümler ışığında öğretim elemanlarının dijital okuryazarlık durumlar1. Journal of Human Sciences, 18(3), 374-389. doi:10.14687/jhs.v18i3.6131

Tablo 4. Öğretim Elemanlarının Kişisel Web Sitesine Sahip Olma, Bilgisayar Kullanım Amacı ve Günlük İnternete Bağlanma Durumu/Düzeyi ile Dijital Okuryazarlık Ölçeği ve Alt Boyutlarından Aldıkları Puan Ortalamaları ve Karşılaştırılması

$\begin{array}{lllllll}\mathbf{n} & \text { Farkındalık } & \text { Bağlamsal } & \text { Güvenli } & \text { Dijital } & \text { Temel } \\ \mathbf{( \% )} & & \text { Kullanım } & \text { Katılım } & \text { Kimlik } & \begin{array}{l}\text { Araç veplam } \\ \text { Ortam } \\ \text { Bilgisi }\end{array} & \\ & & & & & & \\ & & & & & & \end{array}$

\begin{tabular}{|c|c|c|c|c|c|c|c|c|}
\hline \multirow{2}{*}{$\begin{array}{l}\text { Kişisel web } \\
\text { sitesine } \\
\text { sahip olma } \\
\text { durumu }\end{array}$} & Evet & $\begin{array}{l}43 \\
(15.8)\end{array}$ & $74.60 \pm 12.98$ & $40.72 \pm 7.66$ & $25.11 \pm 5.90$ & $16.13 \pm 3.81$ & $21.58 \pm 4.93$ & $178.04 \pm 33.62$ \\
\hline & Hayır & $\begin{array}{l}229 \\
(84.2)\end{array}$ & $70.93 \pm 11.63$ & $38.17 \pm 6.73$ & $23.05 \pm 5.08$ & $15.44 \pm 3.13$ & $18.6 \pm 4.14$ & $167.36 \pm 27.44$ \\
\hline \multirow{2}{*}{\multicolumn{2}{|c|}{ Test ve Anlamlilık }} & & $\mathrm{t}: 1.86$ & $\mathrm{t}: 2.22$ & $\mathrm{t}: 2.37$ & $\mathrm{t}: 1.13$ & $\mathrm{t}: 3.68$ & $\mathrm{t}: 2.25 \mathrm{p}: \mathbf{0 . 0 2}$ \\
\hline & & & p:0.06 & $\mathrm{p}: 0.02$ & $\mathrm{p}: 0.01$ & p:0.26 & $\mathrm{p}: 0.00$ & \\
\hline \multicolumn{9}{|c|}{ Bilgisayarı kullanım amacı } \\
\hline \multirow[t]{2}{*}{$\begin{array}{l}\text { Internete } \\
\text { girmek }\end{array}$} & Evet & $\begin{array}{l}254 \\
(93.4)\end{array}$ & $71.45 \pm 11.99$ & $38.57 \pm 6.96$ & $23.35 \pm 5.32$ & $15.53 \pm 3.26$ & $19.40 \pm 4.39$ & $168.95 \pm 28.84$ \\
\hline & Hayır & $\begin{array}{l}18 \\
(6.6)\end{array}$ & $72.44 \pm 11.00$ & $38.50 \pm 6.86$ & $23.77 \pm 4.46$ & $15.83 \pm 3.14$ & $18.94 \pm 4.19$ & $170.38 \pm 27.43$ \\
\hline \multirow{2}{*}{\multicolumn{2}{|c|}{ Test ve Anlamlılık }} & & t:-0.34 & $\mathrm{t}: 0.04$ & t:-0.32 & t:-0.38 & $\mathrm{t}: 0.43$ & t:-0.20 p:0.83 \\
\hline & & & p:0.73 & $\mathrm{p}: 0.96$ & $\mathrm{p}: 0.74$ & p:0.70 & $\mathrm{p}: 0.66$ & \\
\hline \multirow{2}{*}{$\begin{array}{l}\text { Web } \\
\text { sayfası } \\
\text { oluşturmak }\end{array}$} & Evet & $\begin{array}{l}45 \\
(16.5)\end{array}$ & $75.53 \pm 12.03$ & $41.68 \pm 5.62$ & $25.86 \pm 5.24$ & $16.66 \pm 3.54$ & $22.57 \pm 3.75$ & $182.20 \pm 28.03$ \\
\hline & Hayır & $\begin{array}{l}227 \\
(83.5) \\
\end{array}$ & $70.72 \pm 11.75$ & $37.95 \pm 7.02$ & $22.88 \pm 5.14$ & $15.33 \pm 3.15$ & $18.74 \pm 4.21$ & $166.44 \pm 28.18$ \\
\hline \multirow{2}{*}{\multicolumn{2}{|c|}{ Test ve Anlamlılık }} & & $\mathrm{t}: 2.49$ & $\mathrm{t}: 3.89$ & $\mathrm{t}: 3.53$ & $\mathrm{t}: 2.54$ & $\mathrm{t}: 5.66$ & $\mathrm{t}: 3.42$ \\
\hline & & & p:0.01 & p:0.000 & p:0.000 & $\mathrm{p}: 0.01$ & $\mathrm{p}: 0.000$ & $\mathrm{p}: 0.001$ \\
\hline \multirow[t]{2}{*}{$\begin{array}{l}\text { Eğitsel } \\
\text { amaçlı }\end{array}$} & Evet & $\begin{array}{l}244 \\
(89.7)\end{array}$ & $72.81 \pm 10.66$ & $39.54 \pm 5.92$ & $23.84 \pm 4.98$ & $15.80 \pm 3.08$ & $19.70 \pm 4.14$ & $172.46 \pm 25.25$ \\
\hline & Hayır & $\begin{array}{l}28 \\
(10.3)\end{array}$ & $60.17 \pm 15.83$ & $30.07 \pm 9.17$ & $19.32 \pm 6.02$ & $13.35 \pm 3.84$ & $16.50 \pm 5.25$ & $139.32 \pm 38.85$ \\
\hline \multirow{2}{*}{\multicolumn{2}{|c|}{ Test ve Anlamlilık }} & & $\mathrm{t}: 4.11$ & $\mathrm{t}: 5.34$ & $\mathrm{t}: 4.45$ & $\mathrm{t}: 3.86$ & $\mathrm{t}: 3.76$ & $\mathrm{t}: 4.40$ \\
\hline & & & $\mathrm{p}: 0.000$ & $\mathrm{p}: 0.000$ & $\mathrm{p}: 0.000$ & $\mathrm{p}: 0.000$ & $\mathrm{p}: 0.000$ & $\mathrm{p}: 0.000$ \\
\hline \multirow{2}{*}{$\begin{array}{l}\text { Film } \\
\text { izlemek ve } \\
\text { müzik } \\
\text { dinlemek }\end{array}$} & Evet & $\begin{array}{l}112 \\
(41.2)\end{array}$ & $69.46 \pm 13.70$ & $37.12 \pm 7.63$ & $23.67 \pm 5.49$ & $15.70 \pm 3.14$ & $19.43 \pm 4.24$ & $165.65 \pm 32.09$ \\
\hline & Hayır & $\begin{array}{l}160 \\
(58.8)\end{array}$ & $72.95 \pm 10.27$ & $39.58 \pm 6.24$ & $23.17 \pm 5.11$ & $15.44 \pm 3.33$ & $19.33 \pm 4.47$ & $171.43 \pm 25.92$ \\
\hline \multirow{2}{*}{\multicolumn{2}{|c|}{ Test ve Anlamlılık }} & & $\mathrm{t}:-2.28$ & t:-2.81 & $\mathrm{t}: 0.77$ & $\mathrm{t}: 0.65$ & $\mathrm{t}: 0.18$ & t:-1.57 p:0.11 \\
\hline & & & p:0.02 & $\mathrm{p}: 0.005$ & $\mathrm{p}: 0.43$ & $\mathrm{p}: 0.51$ & $\mathrm{p}: 0.85$ & \\
\hline \multirow{4}{*}{$\begin{array}{l}\text { Günlük } \\
\text { internete } \\
\text { bağlanma } \\
\text { durumu }\end{array}$} & $\begin{array}{l}1 \text { saate } \\
\text { kadar }\end{array}$ & $\begin{array}{l}21 \\
(7.7)\end{array}$ & $66.33 \pm 14.52$ & $35.42 \pm 8.39$ & $20.90 \pm 5.65$ & $14.76 \pm 3.81$ & $17.52 \pm 5.22$ & $155.61 \pm 35.55$ \\
\hline & $\begin{array}{l}1-3 \\
\text { saat } \\
\end{array}$ & $\begin{array}{l}88 \\
(32.4) \\
\end{array}$ & $67.68 \pm 12.47$ & $36.14 \pm 7.39$ & $21.76 \pm 4.62$ & $14.73 \pm 2.96$ & $18.03 \pm 3.83$ & $158.87 \pm 28.57$ \\
\hline & $\begin{array}{l}-5 \\
\text { saat }\end{array}$ & $\begin{array}{l}91 \\
(33.5) \\
\end{array}$ & $72.30 \pm 11.44$ & $39.30 \pm 6.32$ & $24.10 \pm 5.46$ & $15.65 \pm 3.37$ & $19.52 \pm 4.35$ & $171.75 \pm 27.53$ \\
\hline & $\begin{array}{l}5 \\
\text { saatten } \\
\text { fazla }\end{array}$ & $\begin{array}{l}72 \\
(26.5)\end{array}$ & $76.72 \pm 8.2$ & $41.52 \pm 5.16$ & $25.16 \pm 4.87$ & $16.63 \pm 2.96$ & $21.37 \pm 4.0$ & $181.98 \pm 21.63$ \\
\hline \multirow{2}{*}{\multicolumn{2}{|c|}{ Test ve Anlamlılık }} & & F:9.98 & $F: 10.75$ & $F: 8.27$ & F:5.19 & F:9.95 & $\mathrm{F}: 11.57$ \\
\hline & & & p:0.000 & p:0.000 & p:0.000 & p:0.002 & $\mathrm{p}: 0.000$ & p:0.000 \\
\hline \multirow{3}{*}{$\begin{array}{l}\text { İnternet } \\
\text { kullanım } \\
\text { düzeyi }\end{array}$} & İyi & $\begin{array}{l}151 \\
(55.5) \\
\end{array}$ & $76.48 \pm 8.16$ & $42.05 \pm 4.0$ & $25.55 \pm 4.21$ & $16.67 \pm 2.82$ & $21.45 \pm 3.32$ & $182.63 \pm 18.82$ \\
\hline & Orta & $\begin{array}{l}112 \\
(41.2) \\
\end{array}$ & $65.75 \pm 12.44$ & $34.62 \pm 7.14$ & $20.79 \pm 5.13$ & $14.25 \pm 3.06$ & $16.98 \pm 4.02$ & $153.33 \pm 28.76$ \\
\hline & Kötü & $\begin{array}{l}9 \\
(3.3) \\
\end{array}$ & $60.0 \pm 18.11$ & $29.22 \pm 8.8$ & $19.11 \pm 6.19$ & $12.88 \pm 4.8$ & $14.44 \pm 5.34$ & $136.66 \pm 40.94$ \\
\hline \multicolumn{3}{|c|}{ Test ve Anlamlılık } & $\begin{array}{l}\text { F:39.0 } \\
\text { p:0.000 }\end{array}$ & $\begin{array}{l}\text { F:67.59 } \\
\text { p:0.000 }\end{array}$ & $\begin{array}{l}F: 37.14 \\
\text { p:0.000 }\end{array}$ & $\begin{array}{l}\text { F:24.68 } \\
\text { p:0.000 }\end{array}$ & $\begin{array}{l}F: 55.24 \\
\text { p:0.000 }\end{array}$ & $\begin{array}{l}F: 55.13 \\
\text { p:0.000 }\end{array}$ \\
\hline
\end{tabular}


Işık, B., Özdemir, N., \& Kuşlu, S. (2021). Bilgi ve iletişim teknolojilerindeki dönüşümler 1şığında öğretim elemanlarının dijital okuryazarlık durumlar1. Journal of Human Sciences, 18(3), 374-389. doi:10.14687/jhs.v18i3.6131

\%15,8’inin kişisel web sitesi olduğu, \%93,4’ünün bilgisayarı internete girmek amacıyla, \%89,7'sinin ise eğitsel amaçlı kullandığı belirlenmiştir. \% 55,5’inin interneti iyi düzeyde kullandığını ifade ettiği, \% 33,5’i günde 3-5 saat internete bağlandığını ifade etmişstir (Tablo 4).

Tablo 5. Öğretim Elemanlarının İnternet Kullanım Amacı ile Dijital Okuryazarlık Ölçeği ve Alt Boyutlarından Aldıkları Puan Ortalamaları ve Karşılaştırılması

\begin{tabular}{|c|c|c|c|c|c|c|c|c|}
\hline & & $\mathrm{n}(\%)$ & Farkındalık & $\begin{array}{l}\text { Bağlamsal } \\
\text { Kullanım }\end{array}$ & $\begin{array}{l}\text { Güvenli } \\
\text { Katılım }\end{array}$ & $\begin{array}{l}\text { Dijital } \\
\text { Kimlik }\end{array}$ & $\begin{array}{l}\text { Temel } \\
\text { Araç ve } \\
\text { Ortam } \\
\text { Bilgisi } \\
\end{array}$ & Toplam \\
\hline \multicolumn{9}{|c|}{ İnterneti kullanma amacı } \\
\hline \multirow[t]{2}{*}{$\begin{array}{l}\text { Araştırma } \\
\text { yapmak }\end{array}$} & Evet & $\begin{array}{l}251 \\
(92.3) \\
\end{array}$ & $72.96 \pm 10.58$ & $39.50 \pm 6.04$ & $23.80 \pm 5.05$ & $15.80 \pm 3.11$ & $19.70 \pm 4.18$ & $172.47 \pm 25.56$ \\
\hline & Hayır & $21(7.7)$ & $54.28 \pm 13.51$ & $27.47 \pm 7.51$ & $18.28 \pm 5.25$ & $12.47 \pm 3.40$ & $15.52 \pm 4.90$ & $128.09 \pm 33.00$ \\
\hline \multicolumn{3}{|c|}{ Test ve Anlamlılık } & $\begin{array}{l}\text { t:7.58 } \\
\text { p:0.000 }\end{array}$ & $\begin{array}{l}\mathrm{t}: 8.58 \\
\mathrm{p}: \mathbf{0 . 0 0 0}\end{array}$ & $\begin{array}{l}\text { t:4.79 } \\
\text { p:0.000 }\end{array}$ & $\begin{array}{l}\mathrm{t}: 4.68 \\
\mathrm{p}: \mathbf{0 . 0 0 0}\end{array}$ & $\begin{array}{l}\mathrm{t}: 4.33 \\
\mathrm{p}: \mathbf{0 . 0 0 0}\end{array}$ & $\begin{array}{l}\text { t:7.45 } \\
\text { p:0.000 }\end{array}$ \\
\hline \multirow{2}{*}{$\begin{array}{l}\text { Yeni } \\
\text { insanlarla } \\
\text { tanışmak }\end{array}$} & Evet & $\begin{array}{l}37 \\
(13.6) \\
\end{array}$ & $69.70 \pm 14.15$ & $36.83 \pm 8.14$ & $23.64 \pm 5.65$ & $15.56 \pm 3.37$ & $19.86 \pm 4.51$ & $165.64 \pm 34.49$ \\
\hline & Hayır & $\begin{array}{l}235 \\
(86.4) \\
\end{array}$ & $71.80 \pm 11.52$ & $38.84 \pm 6.71$ & $23.34 \pm 5.21$ & $15.54 \pm 3.23$ & $19.30 \pm 4.35$ & $169.58 \pm 27.74$ \\
\hline \multicolumn{3}{|c|}{ Test ve Anlamlılık } & $\mathrm{t}:-0.85 \mathrm{p}: 0.39$ & $\begin{array}{l}\text { t:-1.42 } \\
\text { p:0.16 }\end{array}$ & $\begin{array}{l}\mathrm{t}: 0.33 \\
\mathrm{p}: 0.74\end{array}$ & $\begin{array}{l}\text { t:0.03 } \\
\mathrm{p}: 0.97\end{array}$ & $\begin{array}{l}\text { t:0.72 } \\
\mathrm{p}: 0.46\end{array}$ & t:-0.66 p:0.51 \\
\hline \multirow[t]{2}{*}{$\begin{array}{l}\text { Sohbet } \\
\text { etmek }\end{array}$} & Evet & $\begin{array}{l}82 \\
(30.1) \\
\end{array}$ & $70.30 \pm 13.40$ & $37.74 \pm 7.55$ & $23.87 \pm 5.02$ & $15.37 \pm 3.04$ & $20.17 \pm 4.15$ & $167.53 \pm 31.12$ \\
\hline & Hayır & $\begin{array}{l}190 \\
(69.9) \\
\end{array}$ & $72.04 \pm 11.20$ & $38.93 \pm 6.65$ & $23.16 \pm 5.37$ & $15.62 \pm 3.34$ & $19.03 \pm 4.43$ & $169.70 \pm 27.66$ \\
\hline \multicolumn{3}{|c|}{ Test ve Anlamlılık } & t:-1.02 p:0.30 & $\mathrm{t}:-1.23$ & $\mathrm{t}: 1.01$ & $\mathrm{t}:-0.57$ & t:1.97 & t:-0.57 p:0.56 \\
\hline \multirow[t]{2}{*}{$\begin{array}{l}\text { Oyun } \\
\text { oynamak }\end{array}$} & Evet & $\begin{array}{l}54 \\
(19.9) \\
\end{array}$ & $74.53 \pm 11.66$ & $40.38 \pm 6.25$ & $25.68 \pm 4.62$ & $16.57 \pm 3.10$ & $21.87 \pm 3.45$ & $179.27 \pm 26.92$ \\
\hline & Hayır & $\begin{array}{l}218 \\
(80.1) \\
\end{array}$ & $70.77 \pm 11.87$ & $38.12 \pm 7.04$ & $22.81 \pm 5.27$ & $15.29 \pm 3.24$ & $18.76 \pm 4.36$ & $166.51 \pm 28.63$ \\
\hline \multicolumn{3}{|c|}{ Test ve Anlamlılık } & $\mathrm{t}: 2.09 \mathrm{p:0.03}$ & $\begin{array}{l}\mathrm{t}: 2.16 \\
\mathrm{p}: \mathbf{0 . 0 3}\end{array}$ & $\begin{array}{l}\text { t:3.66 } \\
\text { p:0.000 }\end{array}$ & $\begin{array}{l}\mathrm{t}: 2.60 \\
\mathrm{p}: 0.01\end{array}$ & $\begin{array}{l}\text { t:4.86 } \\
\text { p:0.000 }\end{array}$ & $\mathrm{t}: 2.96 \mathrm{p}: \mathbf{0 . 0 0 3}$ \\
\hline \multirow[t]{2}{*}{$\begin{array}{l}\text { E-posta } \\
\text { göndermek }\end{array}$} & Evet & $\begin{array}{l}255 \\
(93.8) \\
\end{array}$ & $71.82 \pm 11.74$ & $38.83 \pm 6.78$ & $23.45 \pm 5.27$ & $15.58 \pm 3.22$ & $19.5 \pm 4.32$ & $169.85 \pm 28.26$ \\
\hline & Hayır & $17(6.3)$ & $66.94 \pm 13.82$ & $34.7 \pm 8.24$ & $22.29 \pm 5.19$ & $15.0 \pm 3.62$ & $17.41 \pm 4.75$ & $157.05 \pm 33.35$ \\
\hline \multicolumn{3}{|c|}{ Test ve Anlamlılık } & t:1.64 p:0.10 & $\begin{array}{l}\mathrm{t}: 2.39 \\
\mathrm{p}: \mathbf{0 . 0 1}\end{array}$ & $\begin{array}{l}\text { t:0.87 } \\
\text { p:0.38 }\end{array}$ & $\begin{array}{l}\text { t:0.72 } \\
\mathrm{p}: 0.47\end{array}$ & $\begin{array}{l}\mathrm{t}: 1.92 \\
\mathrm{p}: 0.055\end{array}$ & t:1.78 p:0.07 \\
\hline \multirow{2}{*}{$\begin{array}{l}\text { Sosyal } \\
\text { medyayı } \\
\text { takip etmek }\end{array}$} & Evet & $\begin{array}{l}211 \\
(77.6)\end{array}$ & $72.70 \pm 11.39$ & $38.95 \pm 6.77$ & $24.20 \pm 4.92$ & $15.94 \pm 3.07$ & $19.63 \pm 4.28$ & $172.04 \pm 27.79$ \\
\hline & Hayır & $\begin{array}{l}61 \\
(22.4)\end{array}$ & $67.42 \pm 12.80$ & $37.26 \pm 7.4$ & $20.54 \pm 5.48$ & $15.19 \pm 3.5$ & $18.47 \pm 4.58$ & $158.68 \pm 29.65$ \\
\hline \multicolumn{3}{|c|}{ Test ve Anlamlilık } & t:3.09 p:0.002 & t:1.68 p:0.09 & $\begin{array}{l}\mathrm{t}: 4.98 \\
\mathrm{p}: \mathbf{0 . 0 0 0} \\
\end{array}$ & $\begin{array}{l}\mathrm{t}: 3.78 \\
\mathrm{p}: 0.000\end{array}$ & $\begin{array}{l}\mathrm{t}: 1.83 \\
\mathrm{p}: 0.06\end{array}$ & t:3.25 p:0.001 \\
\hline \multirow[t]{2}{*}{$\begin{array}{l}\text { Alışveriş } \\
\text { yapmak }\end{array}$} & Evet & $\begin{array}{l}180 \\
(66.2) \\
\end{array}$ & $73.63 \pm 10.70$ & $39.92 \pm 6.10$ & $24.49 \pm 4.84$ & $16.04 \pm 3.03$ & $20.23 \pm 4.04$ & $174.93 \pm 25.49$ \\
\hline & Hayır & $\begin{array}{l}92 \\
(33.8) \\
\end{array}$ & $67.38 \pm 13.07$ & $35.93 \pm 7.72$ & $21.20 \pm 5.40$ & $14.58 \pm 3.45$ & $17.70 \pm 4.52$ & $157.54 \pm 31.20$ \\
\hline \multicolumn{3}{|c|}{ Test ve Anlamlılık } & $\mathrm{t}: 3.95 \mathrm{p:0.000}$ & $\begin{array}{l}\mathrm{t}: 4.31 \\
\mathrm{p}: \mathbf{0 . 0 0 0}\end{array}$ & $\begin{array}{l}\mathrm{t}: 5.08 \\
\mathrm{p}: \mathbf{0 . 0 0 0}\end{array}$ & $\begin{array}{l}\mathrm{t}: 3.57 \\
\mathrm{p}: \mathbf{0 . 0 0 0}\end{array}$ & $\begin{array}{l}\mathrm{t}: 4.67 \\
\mathrm{p}: \mathbf{0 . 0 0 0}\end{array}$ & $\mathrm{t}: 4.92 \mathrm{p}: \mathbf{0 . 0 0 0}$ \\
\hline \multirow{2}{*}{$\begin{array}{l}\text { Müzik } \\
\text { dinlemek- } \\
\text { film izlemek }\end{array}$} & Evet & $\begin{array}{l}152 \\
(55.9) \\
\end{array}$ & $73.14 \pm 11.35$ & $39.61 \pm 6.57$ & $24.29 \pm 5.08$ & $16.05 \pm 3.16$ & $20.05 \pm 4.31$ & $173.82 \pm 27.14$ \\
\hline & Hayır & $\begin{array}{l}120 \\
(44.1) \\
\end{array}$ & $69.45 \pm 12.32$ & $37.25 \pm 7.19$ & $22.22 \pm 5.29$ & $14.90 \pm 3.26$ & $18.51 \pm 4.31$ & $163.00 \pm 29.60$ \\
\hline \multicolumn{3}{|c|}{ Test ve Anlamlılık } & $\begin{array}{l}\mathrm{t}: 2.56 \\
\mathrm{p}: 0.01\end{array}$ & $\begin{array}{l}\mathrm{t}: 2.83 \\
\mathrm{p}: \mathbf{0 . 0 0 5}\end{array}$ & $\begin{array}{l}\mathrm{t}: 3.27 \\
\mathrm{p}: 0.001\end{array}$ & $\begin{array}{l}\mathrm{t}: 2.93 \\
\mathrm{p}: \mathbf{0 . 0 0 4}\end{array}$ & $\begin{array}{l}\mathrm{t}: 2.92 \\
\mathrm{p}: \mathbf{0 . 0 0 4}\end{array}$ & $\mathrm{t}: 3.13$ p:0.002 \\
\hline \multirow[t]{2}{*}{ Haber takibi } & Evet & $6(2.2)$ & $78.16 \pm 6.82$ & $43.16 \pm 2.13$ & $23.16 \pm 7.57$ & $16.83 \pm 3.06$ & $22.00 \pm 2.52$ & $184.50 \pm 19.07$ \\
\hline & Hayır & $\begin{array}{l}266 \\
(97.8)\end{array}$ & $71.36 \pm 11.96$ & $38.46 \pm 6.97$ & $23.38 \pm 5.22$ & $15.52 \pm 3.25$ & $19.31 \pm 4.39$ & $168.70 \pm 28.82$ \\
\hline \multicolumn{3}{|c|}{ Test ve Anlamlılık } & t:1.38 p:0.16 & $\begin{array}{l}\mathrm{t}: 4.83 \\
\mathrm{p}: \mathbf{0 . 0 0 1}\end{array}$ & $\begin{array}{l}\text { t:-0.10 } \\
\text { p:0.91 }\end{array}$ & $\begin{array}{l}\text { t:0.97 } \\
\text { p:0.33 }\end{array}$ & $\begin{array}{l}\text { t:1.48 } \\
\mathrm{p}: 0.13\end{array}$ & $\mathrm{t}: 1.33 \mathrm{p}: 0.18$ \\
\hline
\end{tabular}


Işık, B., Özdemir, N., \& Kuşlu, S. (2021). Bilgi ve iletişim teknolojilerindeki dönüşümler 1şığında öğretim elemanlarının dijital okuryazarlık durumlar1. Journal of Human Sciences, 18(3), 374-389. doi:10.14687/jhs.v18i3.6131

\% 93,8’inin interneti, e-posta göndermek, \%92,3’ünün ise araştırma yapmak amaciyla kullandığ1 saptanmıştır (Tablo 5).

Tablo 6. Öğretim Elemanlarının İnternete Bağlanmak İçin Kullandıkları Dijital Kaynaklara Göre Dijital Okuryazarlık Ölçeği ve Alt Boyutlarından Aldıkları Puan Ortalamaları ve Karşılaştırılması

\begin{tabular}{|c|c|c|c|c|c|c|c|}
\hline & n ( $\%)$ & Farkındalık & $\begin{array}{l}\text { Bağlamsal } \\
\text { Kullanım }\end{array}$ & $\begin{array}{l}\text { Güvenli } \\
\text { Katılım }\end{array}$ & $\begin{array}{l}\text { Dijital } \\
\text { Kimlik }\end{array}$ & $\begin{array}{ll}\text { Temel } & \\
\text { Araç ve } \\
\text { Ortam } \\
\text { Bilgisi }\end{array}$ & Toplam \\
\hline \multicolumn{8}{|c|}{ İnternete bağlanmak için kullanılan dijital kaynaklar } \\
\hline \multirow{2}{*}{\begin{tabular}{ll} 
Masaüstü & Evet \\
Bilgisayar & \\
\cline { 2 - 2 } Kullanımı & Hayır
\end{tabular}} & $\begin{array}{l}163 \\
(59.9)\end{array}$ & $71.82 \pm 12.20$ & $38.55 \pm 7.04$ & $23.68 \pm 5.35$ & $15.68 \pm 3.36$ & $19.63 \pm 4.42$ & $169.84 \pm 29.47$ \\
\hline & $\begin{array}{l}109 \\
(40.1)\end{array}$ & $71.05 \pm 11.49$ & $38.60 \pm 6.81$ & $22.93 \pm 5.13$ & $15.34 \pm 3.07$ & $19.00 \pm 4.28$ & $167.86 \pm 27.62$ \\
\hline Test ve Anlamlılik & & $\mathrm{t}: 0.52 \mathrm{p}: 0.60$ & $\begin{array}{l}\text { t:-0.06 } \\
\text { p:0.95 }\end{array}$ & $\begin{array}{l}\mathrm{t}: 1.14 \\
\mathrm{p}: 0.25\end{array}$ & $\begin{array}{l}\text { t:0.84 } \\
\text { p:0.40 }\end{array}$ & $\begin{array}{l}\text { t:1.16 } \\
\mathrm{p}: 0.24\end{array}$ & $\mathrm{t}: 0.55 \mathrm{p}: 0.57$ \\
\hline \multirow{2}{*}{$\begin{array}{l}\text { Avuç İçi } \\
\text { Bilgisayar } \\
\text { Kullanımı } \\
\end{array}$} & $7(2.6)$ & $80.85 \pm 6.59$ & $44.14 \pm 1.86$ & $27.0 \pm 3.46$ & $16.0 \pm 4.58$ & $24.0 \pm 2.64$ & $191.71 \pm 16.66$ \\
\hline & $\begin{array}{l}265 \\
(97.4)\end{array}$ & $71.27 \pm 11.92$ & $38.42 \pm 6.96$ & $23.28 \pm 5.27$ & $15.53 \pm 3.22$ & $19.25 \pm 4.34$ & $168.45 \pm 28.73$ \\
\hline Test ve Anlamlılik & & $\begin{array}{l}\text { t:2.11 } \\
\text { p:0.03 }\end{array}$ & $\begin{array}{l}\text { t:6.93 } \\
\text { p:0.00 }\end{array}$ & $\begin{array}{l}\mathrm{t}: 1.84 \\
\mathrm{p}: 0.06\end{array}$ & $\begin{array}{l}\text { t:0.36 } \\
\text { p:0.71 }\end{array}$ & $\begin{array}{l}\mathrm{t}: 2.86 \\
\mathrm{p}: \mathbf{0 . 0 0 4}\end{array}$ & $\mathrm{t}: 2.13 \mathrm{p}: \mathbf{0 . 0 3}$ \\
\hline \multirow{2}{*}{$\begin{array}{l}\text { Dizüstü } \\
\text { Bilgisayar } \\
\text { Kullanımı }\end{array}$} & $\begin{array}{l}233 \\
(85.7)\end{array}$ & $72.39 \pm 11.36$ & $39.20 \pm 6.47$ & $23.76 \pm 5.09$ & $15.67 \pm 3.15$ & $19.68 \pm 4.20$ & $171.35 \pm 27.08$ \\
\hline & $\begin{array}{l}39 \\
(14.3)\end{array}$ & $66.28 \pm 13.78$ & $34.79 \pm 8.41$ & $21.10 \pm 5.78$ & $14.82 \pm 3.75$ & $17.56 \pm 4.96$ & $155.28 \pm 34.25$ \\
\hline Test ve Anlamlılık & & $\mathrm{t}: 2.62 \mathrm{p}: \mathbf{0 . 0 1}$ & $\begin{array}{l}\text { t:3.12 } \\
\text { p:0.003 }\end{array}$ & $\begin{array}{l}\text { t:2.96 } \\
\text { p:0.003 }\end{array}$ & $\begin{array}{l}\text { t:1.52 } \\
\text { p:0.13 }\end{array}$ & $\begin{array}{l}\mathrm{t}: 2.83 \\
\mathrm{p}: \mathbf{0 . 0 0 5}\end{array}$ & $\begin{array}{l}\text { t:2.78 } \\
\text { p:0.008 }\end{array}$ \\
\hline \multirow{2}{*}{$\begin{array}{l}\text { Cep } \\
\text { Telefonu } \\
\text { Kullanımı }\end{array}$} & $\begin{array}{l}247 \\
(90.8)\end{array}$ & $72.38 \pm 11.49$ & $39.13 \pm 6.41$ & $23.89 \pm 4.93$ & $15.81 \pm 3.05$ & $19.66 \pm 4.06$ & $171.51 \pm 26.78$ \\
\hline & $\begin{array}{l}25 \\
(9.2) \\
\end{array}$ & $62.96 \pm 12.75$ & $33.04 \pm 9.31$ & $18.36 \pm 5.94$ & $12.96 \pm 3.99$ & $16.52 \pm 6.14$ & $144.68 \pm 35.69$ \\
\hline Test ve Anlamlılık & & $\begin{array}{l}\mathrm{t}: 3.86 \\
\mathrm{p}: \mathbf{0 . 0 0 0}\end{array}$ & $\begin{array}{l}\mathrm{t}: 3.19 \\
\text { p:0.004 }\end{array}$ & $\begin{array}{l}\mathrm{t}: 5.24 \\
\text { p:0.000 }\end{array}$ & $\begin{array}{l}\mathrm{t}: 4.31 \\
\mathrm{p}: \mathbf{0 . 0 0 0}\end{array}$ & $\begin{array}{l}\mathrm{t}: 2.50 \\
\mathrm{p}: \mathbf{0 . 0 1}\end{array}$ & $\begin{array}{l}\mathrm{t}: 3.65 \\
\text { p:0.001 }\end{array}$ \\
\hline \multirow[t]{2}{*}{$\begin{array}{l}\text { Tablet } \\
\text { Bilgisayar }\end{array}$} & $\begin{array}{l}114 \\
(41.9)\end{array}$ & $70.68 \pm 12.91$ & $38.64 \pm 7.24$ & $23.34 \pm 5.36$ & $15.31 \pm 3.24$ & $20.0 \pm 4.18$ & $168.34 \pm 30.17$ \\
\hline & $\begin{array}{l}158 \\
(58.1)\end{array}$ & $72.12 \pm 11.13$ & $38.51 \pm 6.73$ & $23.41 \pm 5.21$ & $15.72 \pm 3.25$ & $18.93 \pm 4.46$ & $169.56 \pm 27.69$ \\
\hline Test ve Anlamlılık & & $\begin{array}{l}\text { t:-0.98 } \\
\text { p:0.32 }\end{array}$ & $\begin{array}{l}\mathrm{t}: 0.15 \\
\mathrm{p}: 0.87\end{array}$ & $\begin{array}{l}\text { t:-0.10 } \\
\text { p:0.91 }\end{array}$ & $\begin{array}{l}\text { t:-1.01 } \\
\text { p:0.31 }\end{array}$ & $\begin{array}{l}\mathrm{t}: 2.00 \\
\mathrm{p}: \mathbf{0 . 0 4}\end{array}$ & t:-0.34 p:0.73 \\
\hline
\end{tabular}

İnternete bağlanmak için avuç içi ve dizüstü bilgisayar kullananlar ile DOYÖ’nün Farkındalık, Bağlamsal Kullanım, Temel Araç ve Ortam Bilgisi alt boyutları ile toplam puan ortalamaları arasında istatistiki açıdan anlamlı fark olduğu $(\mathrm{p}<0.05)$ ve bu farkın avuç içi ve dizüstü bilgisayar kullananlar lehine olduğu saptanmıştır. İnternete bağlanmak için cep telefonunu kullananlar ile DOYÖ'nün tüm alt boyutları ile toplam puan ortalamaları arasında istatistiki açıdan anlamlı farklılık olduğu $(\mathrm{p}<0.05)$ ve bu farkın cep telefonu kullananlar lehine olduğu belirlenmiştir. İnternete bağlanmak için tablet bilgisayar kullananlar ile DOYÖ’nün Temel Araç ve Ortam Bilgisi alt boyutu puan ortalamaları arasında istatistiki açıdan anlamlı fark olduğu $(\mathrm{p}<0.05)$ ve bu farkın tablet bilgisayar kullananlar lehine olduğu saptanmıştır (Tablo 6).

Eğitim etkinliklerinde, slayt makinesi kullananlar ile DOYÖ'nün, Temel Araç ve Ortam Bilgisi alt boyutu; televizyon-video kullananlar ile Farkındalık, Bağlamsal Kullanım, Güvenli Katılım, Dijital Kimlik alt boyutları; film kullananlar ile tüm alt boyutları; bilgisayar kullananlar ile Bağlamsal Kullanım, Güvenli Katılım, Dijital Kimlik, Temel Araç ve Ortam Bilgisi alt boyutları; barkovizyon kullananlar ile Farkındalık, Bağlamsal Kullanım alt boyutları; akıllı tahta kullananlar ile Temel Araç ve Ortam Bilgisi alt boyutu ile toplam puan ortalamaları arasında istatistiki açıdan ileri düzeyde anlamlı fark olduğu bulunmuştur $(\mathrm{p}<0.05)$ (Tablo 3). 
Işık, B., Özdemir, N., \& Kuşlu, S. (2021). Bilgi ve iletișim teknolojilerindeki dönüşümler 1șığında öğretim elemanlarının dijital okuryazarlık durumlar1. Journal of Human Sciences, 18(3), 374-389. doi:10.14687/jhs.v18i3.6131

Kişisel web sitesine sahip olanlar ile DOYÖ’nün Temel Araç ve Ortam Bilgisi, Güvenli Katılım ve Bağlamsal Kullanım alt boyutları ile toplam puan ortalamaları arasında istatistiki açıdan anlamlı fark olduğu saptanmıştır $(\mathrm{p}<0.05)$. Bilgisayar kullanımını web sayfası oluşturmak amacıyla ve eğitsel amaçlı kullananlar, internet kullanım düzeyi iyi olanlar, günlük internete bağlanma süresi 3-5 saat aralığında olanlar ile DOYÖ'nün tüm alt boyutları ile toplam puan ortalamaları arasında istatistiki açıdan ileri düzeyde anlamlı fark olduğu belirlenmiştir $(\mathrm{p}<0.01)$ (Tablo 4).

İnternet kullanımını; araştırma yapmak, oyun oynamak, film izlemek, müzik dinlemek ve alsşveriş yapmak için kullananlar ile DOYÖ'nün tüm alt boyutları ile toplam puan ortalamaları arasında istatistiki açıdan ileri düzeyde anlamlı fark olduğu belirlenmiştir $(\mathrm{p}<0.01)$ (Tablo 5).

\section{TARTIŞMA}

Bir üniversitenin değişik fakülte ve yüksekokullarında görev yapmakta olan öğretim elemanlarının dijital okuryazarlık düzeylerini ve etkileyen faktörleri belirlemek amacı ile yapılan bu çalışmada, öğretim elemanlarının dijital okuryazarlık konusunda "çok yeterli" oldukları belirlenmiştir. Aynı zamanda, dijital okuryazarlı̆̆ın alt boyutlarını oluşturan Dijital Kimlik, Bağlamsal Kullanım, Farkındalık, Güvenli Katılım ve Temel Araç ve Ortam Bilgisi konusunda da “çok yeterli” düzeyde oldukları saptanmıştır. Bu sonuçlar, üniversitede görev yapan öğretim elemanlarının eğitimde güncel gelişmeleri hızlı yakaladıklarını ve takip ettiklerini, dijitalleşmede sorun yaşamadıklarını ve bilgi ve iletişim teknolojilerini aktif olarak kullandıklarını düşündürmektedir. Üniversitelerde öğrenim gören gençlerin/öğrencilerin dijital teknolojileri kullanmaya yönelik yatkınlıkları ve çok yüksek düzeyde kullanım durumları gözönüne alındığında, bu sonuçların öğrenme-öğretme süreci, öğrenciler ve toplum açısından sevindirici olduğu söylenebilir. İlgili literatür incelendiğinde, öğretim elemanlarının dijital okuryazarlık becerisini ele alan çalışmaların ülkemizde çok az düzeyde olduğuna rastlanmıştır. Farklı çalışma grupları ve farklı dijital okuryazarlık ölçeği kullanılarak yapılan benzer çalışmalar, araştırma sonuçlarını desteklemektedir.

Şahin ve ark. (2019)'nın yürüttüğü çalışmada, öğretmenlerin bilişim teknolojilerinde kodlamaya yönelik özyeterliklerinin yüksek düzeyde olduğu belirlenmiştir (Şahin ve ark., 2019). Yurtseven ve ark. (2021)'nın yürüttüğü çalışmada, öğretim elemanlarının dijital yeterliklerinin iyi düzeyde olduğu ve dijital okuryazarlıklarının ise orta düzeyde olduğu, ayrıca, yüksek düzeyde dijital yeterliklere sahip öğretim elemanlarının uzaktan eğitime yönelik algılarının da olumlu olduğu belirlenmiştir. Özerbaş ve Kuralbayeva'nın (2018), öğretmen adayları ile yürüttüğü araştırmada, Türkiye'de bulunan öğretmen adaylarının dijital okuryazarlık yeterliklerinin yeterli düzeyde, Kazakistan'daki öğretmen adayları için orta düzeyde olduğu belirlenmiştir (Özerbaş \& Kuralbayeva, 2018). Ocak ve Karakuş (2019), öğretmen adayları ile yapmış oldukları çalışmada, öğretmen adaylarının dijital okuryazarlık öz-yeterliliğinin yüksek olduğunu saptamıştır (Ocak \& Karakuş, 2019). Kozan ve Bulut-Özek (2019), BÖTE Bölümü’nde öğrenim gören öğrencilerin dijital okuryazarlık düzeylerini ve siber zorbalık hakkındaki duyarlılıklarını belirlemek için yapmış oldukları çalışmada, öğrencilerin dijital okuryazarlık düzeyinin yüksek olduğunu belirlemiştir (Kozan \& BulutÖzek, 2019). Yontar (2019) çalışmasında, öğretmen adaylarının dijital okuryazarlık düzeyinin orta düzeyde olduğunu saptamıştır (Yontar, 2019). Özbek (2020), 128 öğretmen ile yapmış olduğu çalışmada öğretmenlerin dijital içerik ve teknolojiyi kullanabilme becerilerinin iyi düzeyde olduğunu belirlemiştir (Özbek, 2020). Özdurak ve ark. (2020) çalışmalarında, öğretmenlerin teknopedagojik yeterliklerinin ve teknolojik bilgi düzeylerinin yüksek olduğunu belirlemişlerdir (Özdurak-Sıngın \& Gökbulut, 2020). Üstündağ ve ark. (2017), Yllmaz ve ark. (2015), Ata ve Yıldırım (2019) öğretmen adayları ile yapmış oldukları araştırmalarda, öğretmen adaylarının dijital okuryazarlık durumlarının iyi düzeyde olduğunu saptamıştır (Üstündağ ve ark., 2017; Yılmaz ve ark., 2015; Ata \& Yıldırım, 2019). Öztürk (2021)'ün çalışmasında pandemi nedeniyle uzaktan eğitim sistemine geçişle birlikte öğretim elemanlarının dijital ortamda ders verme ve ders materyalleri hazırlama/kullanma konusunda kendilerini yetersiz hissettikleri belirlenmiştir. Durak ve ark. (2020) çalışmalarında öğretim elemanlarının bir kısmının uzaktan eğitim sürecine hazır olmadıklanını ve sistemi/dijital teknolojileri 
Işık, B., Özdemir, N., \& Kuşlu, S. (2021). Bilgi ve iletişim teknolojilerindeki dönüşümler 1şığında öğretim elemanlarının dijital okuryazarlık durumlar1. Journal of Human Sciences, 18(3), 374-389. doi:10.14687/jhs.v18i3.6131

kullanmakta zorlandıklanını belirlemişlerdir. Bozkurt’un (2020) çalışmasında, eğitimcilerin bir kısmının, uzaktan eğitim sistemine yönelik dijital becerilere sahip olmadığı ve bu durumun onları zorladığ1 belirlenmiştir. Bu sonuçlar, eğitimcilerin ve eğitimci adaylarının, interneti ve dijital teknolojileri çağdaş yaşamın kaçınılmaz bir parçası olarak gördüklerini, dijital teknolojilerin eğitsel, sosyal, toplumsal ve bireysel katkıları konusunda farkındalıklarının yüksek olduğunu düşündürmüştür.

Çalışmamızda, erkek öğretim elemanlarının kadın öğretim elemanlarına göre Temel Araç ve Ortam Bilgisi alt boyutundan daha yüksek puan aldığı ve erkekler lehine anlamlı farklılık olduğu belirlenmiştir. Ayrıca, erkek öğretim elemanlarının tüm alt boyutlarda ve ölçeğin genelinde kadınlara göre daha yüksek puan aldığ1 belirlenmiştir. Akgün (2019)'ün çalışmasında erkek öğretim elemanlarının kadın öğretim elemanlarına göre teknolojiyi kabul algılarının daha yüksek olduğu belirlenmiştir. Elçi ve Sarı (2016), öğrenciler ile yaptıkları çalışmada, cinsiyete göre dijital okuryazarlık düzeyi arasında anlamlı bir fark olmadığını belirlemiştir (Elçi \& Sarı, 2015). Yontar (2019), Ata ve Yıldırım (2019) öğretmen adayları ile yürüttükleri çalısmalarında, kadınların dijital okuryazarlık yeterliliklerinin orta düzeyde, erkeklerin yüksek düzeyde olduğunu belirlemiştir (Yontar, 2019; Ata \& Yıldırım, 2019). Kul (2020) öğrenciler ile yapmış olduğu çalışmada, kız öğrencilerin dijital okuryazarlıklarının daha yüksek olduğunu belirlemiştir (Kul, 2020). Özerbaş ve Kuralbayeva (2018), çalışmalarında, erkek öğretmen adaylarının dijital okuryazarlık düzeyinin kadınlara göre daha yüksek olduğunu saptamıştır (Özerbaş \& Kuralbayeva, 2018). Tekin ve Polat (2017) erkeklerin dijital yetkinlikte kadınlardan daha fazla kendilerine güvendiklerini saptamıstır (Tekin \& Polat, 2017). Ocak ve Karakuş (2019), Kozan ve Bulut-Özek (2019), Teo et.al. (2015), Tanduer et.al. (2018), Aslan ve Zhu (2017), Argelagos ve Pifarre (2017) çalışmalarında, dijital okuryazarlık durumunun cinsiyete göre farklılaşmadığını saptamışlardır (Ocak \& Karakuş, 2019; Kozan \& Bulut-Özek, 2019; Teo et al., 2015; Tondeur et al., 2018; Aslan \& Zhu, 2017; Argelagos \& Pifarre, 2017). Özbek (2020), öğretmenler ile yürüttüğü çalş̧mada, öğretmenlerin dijital içerik ve teknolojiyi kullanma becerilerinin, cinsiyete göre farkllık göstermediğini belirlemiştir (Özbek, 2020). $\mathrm{Bu}$ sonuçlar, dijital okuryazarlık becerileri ve bu teknolojileri kullanma yetkinlikleri konusunda, kadınlar aleyhine bir yetersizliği belirtmekle birlikte, erkeklerin dijital teknolojileri kullanmaya daha yatkın olduklarını, dijital teknolojilere özel ve mesleki yaşamlarında daha fazla zaman ayırdıklarını düşündürmüştür.

Çalışmamızda, 22-27 yaş grubunda bulunan öğretim elemanlarının, okutmanların ve öğretim elemanı olarak 3-5 yıl çalışma süresine sahip olan öğretim elemanlarının dijital okuryazarlık düzeylerinin diğer gruplara göre çok daha yüksek olduğu belirlenmiştir. TÜíK'in (2019) yll "Hanehalkı Bilişim Teknolojileri Kullanım Araştırması"”nda, 25-34 yaş grubundaki bireylerin internet kullanım oranlarının $(\% 91,7)$ diğer yaş gruplarına göre oldukça yüksek düzeyde olduğu saptanmıştır (TÜİK, 2019). Yılmaz ve ark. (2015)'nın yürüttüğü çalışmada, 24 ve üzeri yaş grubundaki öğretmen adaylarının diğer yaşlara göre dijital okuryazarlık düzeylerinin yüksek olduğunu saptamışlardır (Yılmaz ve ark., 2015). Şimşek ve ark.'nın (2013) yürüttüğü çalışmada, araştırma görevlisi olarak görev yapan, 30 yaş ve altında bulunan öğretim elemanlarının teknopedagojik eğitim yeterliklerinin yüksek düzeyde olduğu belirlenmiştir (Şimşek ve ark., 2013). Yontar (2019) öğretmen adayları ile yaptı̆̆ çalışmada yaş ile dijital okuryazarlık yeterliği arasında istatistiksel olarak anlamlı bir ilişki olmadığını belirlemiştir (Yontar, 2019). Prensky (2001), 1980 ylı sonrasında doğanları dijital teknolojilerin içinde büyüyen ve bu teknolojileri etkin olarak kullanabilen dijital yerliler olarak tanımlamaktadır. Buna göre, genç yaştaki öğretim elemanlarının dijital teknolojilerle daha erken dönemde tanışmalarının, dijital okuryazarlık düzeyleri üzerinde önemli rol oynadığ1 görülmektedir (Prensky, 2001).

İnternete bağlanmak için dizüstü, avuçiçi bilgisayar ve cep telefonu kullanan, eğitim etkinliklerinde yoğun olarak bilgisayar, televizyon-video, film ve slayt makinesi kullanan, kişisel web sitesine sahip olan, bilgisayarı; web sayfası oluşturmak, eğitsel amaçlı kullanmak, film izlemek ve müzik dinlemek amacıyla kullanan, interneti; araştırma yapmak, oyun oynama, alıs-veriş yapmak, sosyal medyayı takip etmek, film izlemek ve müzik dinlemek amacıyla, iyi düzeyde ve 
Işık, B., Özdemir, N., \& Kuşlu, S. (2021). Bilgi ve iletișim teknolojilerindeki dönüşümler 1șığında öğretim elemanlarının dijital okuryazarlık durumlar1. Journal of Human Sciences, 18(3), 374-389. doi:10.14687/jhs.v18i3.6131

günde 5 saatten fazla kullanan, öğretim elemanlarının dijital okuryazarlık düzeylerinin diğer gruplara göre daha yüksek olduğu saptanmıştır. Keleş ve Güntepe (2018)'nin yürüttüğü çalışmada, öğretim elemanlarının çoğunluğunun derse hazırlanırken ve dersi sunarken bilgisayar, projeksiyon ve internet vb. teknolojik araçları kullandığı saptanmıştır (Keleş \& Güntepe, 2018). Bu durumun; sözü edilen teknolojilere tüm sınıflarda kolaylıkla erişilebilmesi, ve öğretim elemanlarının bu teknolojik araçları kullanma konusunda kendilerini daha yeterli düzeyde değerlendirmesinden kaynaklandığ1 söylenebilir. Ekiz, Yavuz ve Hüseyin (2003), öğrenme-öğretme sürecinde kullanılan bu teknolojik araçların eğitimcinin aktif olduğu bir öğrenme ortamını ön plana çıkardığını savunmaktadır (Ekiz ve ark., 2003). Kısa'nın (2005) yürüttüğü çalışmada, hemşire öğretim elemanlarının çoğunluğunun, eğitim etkinliklerinde; bilgisayar, projeksiyon, televizyon-film-video, slayt makinesi kullandıkları saptanmıştır (Kısa, 2005). Yılmaz ve ark. (2015)'nın çalışmasında, öğrencilerin, dijital teknolojileri kullanım düzeylerinin iyi olmasını, bilgisayara ve internet erişimine sahip olmaya bağladıkları görülmüştür ( Yılmaz ve ark., 2015). Bu sonuçlar doğrultusunda, öğretim elemanlarının dijital teknolojileri eğitim etkinliklerine entegre etmesi, öğretme-öğrenme süreci açısından memnun edici olarak ele alınabilir.

\section{SONUÇ VE ÖNERİLER}

Çalışma sonuçları, öğretim elemanlarının dijital okuryazarlık düzeylerinin çok yüksek olduğunu, yaş, cinsiyet, akademik unvan, çalışma yllı değişkenlerinin dijital okuryazarlık düzeyini etkilediği, öğretim elemanlarının dijital teknolojileri eğitim etkinliklerinde büyük oranda kullandıklanını göstermektedir. Dijital ortamlarda bilgiye ulaşmayı, bilgiyi etkin olarak kullanmayı, doğru ve geçerli bilgiyi ayırt edebilmeyi ve yeni bilgi üretmeyi sağlayan dijital okuryazarlık becerisi, öğrenme-öğretme süreçleri için vazgeçilmez bir unsur olarak ele alınmakta ve öğretim elemanlarının yükseköğretim kurumlarının dönüşmesi, dijitalleşmesi ve gelişmesi sürecinde aktif olmaları bir gereklilik olarak görülmektedir. Dijital okuryazarlık becerilerinin kazandırlması, güncel bilgiler 1şığında yeniliklerden haberdar edilmeleri, yükseköğretim için yaşamsal düzeyde önem taşımaktadır. Bu bağlamda, dijital dönüşümün tüm kurumları ve sistemleri olduğu gibi üniversiteleri de çok derinden etkilediğini anlamak, üniversitenin misyon ve vizyonu doğrultusunda dijital etkinlikleri yapılandırmak ve dijital dönüşümün ışığında eğitim sistemlerinin yeniden tanımlanmasını sağlamak yükseköğretim kurumları için anahtar konumdadır. Bu sonuçlar doğrultusunda; yükseköğretim kurumlarında sürekli eğitim etkinlikleri kapsamında dijital okuryazarlık becerilerine ilişkin eğitim etkinlikleri düzenlenmesi, özellikle ve öncelikle, ileri yaş grubunda yer alan öğretim elemanları ve kadın öğretim elemanlarının dijital okuryazarlık eğitimlerine öncelikle katulmaları, öğretim elemanlarının teknolojiyi öğrenme-öğretme sürecine entegre edebilmesi için üniversitelerde teknik destek birimlerinin kurulması ve öğretim elemanlarının, eğitim etkinliklerinde, dijital teknolojileri doğru ve etkin kullanması yönünde motive edilmesi sağlanmalıdır.

\section{KAYNAKLAR}

Acar Ç. (2015). Anne ve Babaların İlkokul Ortaokul ve Lise Öğrencisi Çocukları ile Kendilerinin Dijital Okuryazarlıklarına İlişkin Görüşleri. T.C. Ankara Üniversitesi Eğitim Bilimleri Enstitüsü Bilgisayar ve Öğretim Teknolojileri Eğitimi Anabilim Dalı Eğitim Teknolojisi Program1. Ankara, Turkey.

Ak, Ş, Gökdaş, İ, Öksüz, C, Torun, F. (2021). Uzaktan eğitimde eğiticilerin eğitimi: Uzaktan eğitime yönelik öz yeterlik ve yarar algısına etkisi. Açıköğretim Uygulamaları ve Araştırmaları Dergisi, $\quad 7(1)$, 24-44. Retrieved from https://dergipark.org.tr/en/pub/auad/issue/60075/826745.

Akgün, F. (2019). Öğretim Elemanlarının Bilgi ve İletişim Teknolojilerine Yönelik Kabulleri ve Teknostres Algıları Arasındaki İlişkinin İncelenmesi. Eğitim Bilimleri Araştırmaları Dergisi, 9(2), 40-66. Retrieved from https://dergipark.org.tr/en/pub/ebader/issue/49386/558622.

Argelagos E, Pifarre M. (2017). Unravelling Secondary Students' Challenges in Digital Literacy: A Gender Perspective. Journal of Education and Training Studies, 5 (1), 42-55. 
Işık, B., Özdemir, N., \& Kuşlu, S. (2021). Bilgi ve iletişim teknolojilerindeki dönüşümler 1şığında öğretim elemanlarının dijital okuryazarlık durumlar1. Journal of Human Sciences, 18(3), 374-389. doi:10.14687/jhs.v18i3.6131

Aslan A, Zhu C. (2017). Investigating Variables Predicting Turkish Pre-service Teachers' Integration of ICT into Teaching Practices. British Journal of Educational Technology, 48 (2), 552-570.

Ata R, Yildırm K. (2019). Exploring Turkish Pre-service Teachers' Perceptions and Views of Digital Literacy. Education Sciences, 9 (1), 40.

Benali M, Kaddouri M, Azzimani T. (2018). Digital Competence of Moroccan Teachers of English. International Journal of Education and Development using ICT, 14 (2).

Bozkurt, A. (2020). Koronavirüs (Covid-19) pandemi süreci ve pandemi sonrası dünyada eğitime yönelik değerlendirmeler: Yeni normal ve yeni eğitim paradigması. Açıköğretim Uygulamaları ve Araşturmaları Dergisi, 6(3), 112-142.

Churchill N, Ping LC, Oakley G, Churchill D. (2008). Digital Storytelling and Digital Literacy Learning. In Proceedings of International Conference on Information Communication Technologies in Education (ICICTE), (pp. 418-430).

Compagno G, Cappuccio G, Pedone F. (2016). Digital Competence for the Improvement of Special Education Teaching. Journal of e-Learning and Knowledge Society, 12 (4).

Çubukçu A, Bayzan Ş. (2013). Türkiye'de Dijital Vatandaşlık Algısı ve Bu Algıyı İnternetin Bilinçli, Güvenli ve Etkin Kullanımı ile Artırma Yöntemleri. Middle Eastern \& African Journal of Educational Research, 5, 148-174.

Durak, G, Çankaya, S, İzmirli, S. (2020). COVID-19 Pandemi Döneminde Türkiye'deki Üniversitelerin Uzaktan Eğitim Sistemlerinin İncelenmesi. Necatibey Eğitim Fakültesi Elektronik Fen ve Matematik Eğitimi Dergisi, 14 (1), 787-809. DOI: $10.17522 /$ balikesirnef.743080.

Ekiz H, Yavuz B, Ünal H. (2003). Mantık Devreleri Dersine Yönelik Internet Destekli Uzaktan Eğitim Uygulaması. The Turkish Online Journal of Educational Technology, 2 (4), 92-99.

Elçi AC, Sarı M. (2015). Bilişim Teknolojileri ve Yazılım Dersi Öğretim Programına Yönelik Öğrenci Görüşlerinin Dijital Vatandaşlık Bağlamında İncelenmesi. Çukurova Üniversitesi Sosyal Bilimler Enstitüsü Dergisi, 25 (3), 87-102.

Erişti B. (2010). Eğitimde Dönüşümler. Bilgi ve İletişim Teknolojileri Işığında Dönüşümler İçinde, (pp. 1-18). Ankara: Nobel Yayın Dağıtım.

Eshet-Alkalai Y. (2004). Digital Literacy: A Conceptual Framework for Survival Skills in the Digital Era. Journal of Educational Multimedia and Hypermedia, 13 (1), 93-106.

Güçlü N, Yücel C, Karataş E, Karabulut B. (2010). Eğitim Yöneticilerinin Okullarda Bilgi ve İletişim Teknolojilerini Kullanma Standartları. 10th International Educational Technology Conference \& Exhibition, (pp. 461).

Hakim A. (2015). Contribution of Competence Teacher (Pedagogical, Personality, Professional Competence and Social) on the Performance of Learning. The International Journal of Engineering and Science, 4 (2), 1-12.

Hamutoğlu NB, Güngören ÖC, Uyanık GK, Erdoğan DG. (2017). Dijital Okuryazarlık Ölçeği: Türkçe'ye Uyarlama Çalışması. Ege Eğitim Dergisi, 18 (1), 408-429.

ISTE (International Society for Technology in Educators). (2008). Iste Standarts for Educators. Access Adress: www.iste.org Access Date: 24.09.2020.

Keleş E, Güntepe ET. (2018). Eğitim Fakültesi Öğretim Elemanlarının Teknolojiyi ÖğrenmeÖğretme Sürecine Entegrasyonu. Sakarya University Journal of Education, 8 (3), 142-157.

Kısa B. (2005). Hemşire Öğretim Elemanlarının Teknolojiye İlişkin Tutumları. İstanbul Üniversitesi Sağlık Bilimleri Enstitüsü Hemşirelik Öğretimi Anabilim Dalı. İstanbul, Turkey.

Kozan M, Bulut-Özek M. (2019). Böte Bölümü Öğretmen Adaylarının Dijital Okuryazarlık Düzeyleri ve Siber Zorbalığa İlişkin Duyarlllkklarının İncelenmesi. Firat University Journal of Social Sciences/Sosyal Bilimler Dergisi, 29 (1).

Kul S. (2020). Dijital Okuryazarlık ve Diğer Değişkenlerle İnternet Bağımlılığı İlişkisinin İncelenmesi. Uluslararası Yönetim Bilişim Sistemleri ve Bilgisayar Bilimleri Dergisi, 4 (1), 28-41. DOI: 10.33461/uybisbbd.646682. 
Işık, B., Özdemir, N., \& Kuşlu, S. (2021). Bilgi ve iletişim teknolojilerindeki dönüşümler 1şığında öğretim elemanlarının dijital okuryazarlık durumlar1. Journal of Human Sciences, 18(3), 374-389. doi:10.14687/jhs.v18i3.6131

Martin A. (2008). Digital Literacy and the Digital Society. Digital Literacies: Concepts, Policies and Practices, 30, 151-176.

Napal-Fraile M, Penalva-Velez A, Mendioroz Lacambra A. M. (2018). Development of Digital Competence in Secondary Education Teachers' Training. Education Sciences, 8 (3), 104.

Ng W. (2012). Can We Teach Digital Natives Digital Literacy?. Computers \& Education, 59 (3), 1065-1078.

Ocak G, Karakuş DÖG. (2019). Öğretmen Adaylarının Dijital Okuryazarlık Öz-yeterlilik Becerilerinin Farklı Değişkenler Açısından İncelenmesi. Afyon Kocatepe University Journal of Social Sciences, 21 (1).

Özbek Y. (2020). Sınıf Öğretmenlerinin Dijital İçerik ve Teknolojiyi Kullanma Becerileri. T.C. Pamukkale Üniversitesi Eğitim Bilimleri Enstitüsü Eğitim Bilimleri Anabilim Dalı Eğitim Yönetimi, Teftişi, Planlaması ve Ekonomisi Bilim Dalı Tezsiz Yüksek Lisans Projesi. Denizli, Turkey.

Özdurak-Sing1n RH, Gökbulut B. (2020). Okul Öncesi Öğretmenlerinin Teknopedagojik Yeterliklerinin Belirlenmesi. Bolu Abant İzzet Baysal Üniversitesi Eğitim Fakültesi Dergisi, 20 (1), 269-280.

Özerbaş M, Kuralbayeva A. (2018). Türkiye ve Kazakistan Öğretmen Adaylarının Dijital Okuryazarlık Düzeylerinin Değerlendirilmesi. Muğla Sttkı Koçman Üniversitesi Eğitim Fakültesi Dergisi, 5 (1), 16-25. DOI: 10.21666/muefd.314761.

Öztürk, H. (2021). MESLEK YÜKSEKOKULU ÖĞRETIM ELEMANLARININ UZAKTAN EĞITITIM SÜRECINDE UYUMLARININ INCELENMESİ: NITTEL BİR ARAŞTIRMA. Mehmet Akif Ersoy Üniversitesi Eğitim Fakültesi Dergisi, (57), 74-97 . Retrieved from https://dergipark.org.tr/en/pub/maeuefd/issue/60050/808846.

Parlak B. (2017). Dijital Çağda Eğitim: Olanaklar ve Uygulamalar Üzerine Bir Analiz. Süleyman Demirel Üniversitesi İktisadi ve İdari Bilimler Fakültesi Dergisi, 22 (15), 1741-1759.

Prensky M. (2001). Digital natives, digital immigrants. On the horizon, 9 (5).

Redecker C. (2017). European Framework for the Digital Competence of Educators: DigCompEdu. (No. JRC107466). Joint Research Centre (Seville site).

Rokenes FM, Krumsvik RJ. (2016). Prepared to Teach ESL with ICT? A Study of Digital Competence in Norwegian Teacher Education. Computers \& Education, 97, 1-20.

Şahin H, Korkmaz Ö, Çakır R, Uğur Erdoğmuş F. (2019). Bilişim Teknolojileri Öğretmenlerinin Kodlamaya Dönük Tutumları, Öz-yeterlilikleri ve Kodlama Öğretimi İçin Kullandıkları Yöntemler. Ondokuz Mayıs Üniversitesi Eğitim Fakültesi Dergisi, 38 (2), 1-16. DOI: 10.7822/omuefd.612449.

Selimi A, Üseini A. (2019). Yenilikçi Eğitim ile Dijital Yetkinlik ve Girişimcilik Becerilerinin Geliştirilmesi-Kuzey Makedonya Örneği. 2019 In ICEB' 19-International Congress of Economics and Business.

Şimşek Ö, Demir S, Bağçeci B, Kinay İ. (2013). Öğretim Elemanlanının Teknopedagojik Eğitim Yeterliliklerinin Çeşitli Değişkenler Açısından İncelenmesi. Ege Eğitim Dergisi, 14 (1), 1-23.

Tekin A, Polat E. (2017). Öğretmen Adaylarının Sayısal Yetkinlik Düzeyleri ve Çevrimiçi Bilgi Arama Stratejilerinin Değerlendirilmesi. Trakya Üniversitesi Eğitim Fakültesi Dergisi, 7 (2), 635-658.

Teo T, Fan X, Du J. (2015). Technology Acceptance among Pre-service Teachers: Does Gender Matter?. Australasian Journal of Educational Technology, 31 (3).

Timur B, Timur S, Akkoyunlu B. (2014). Öğretmen Adaylarının Sayısal Yetkinlik Düzeylerinin Belirlenmesi. Sosyal ve Beşeri Bilimler Araştırmaları Dergisi, (33), 41-59.

Tondeur J, Aesaert K, Prestridge S, Consuegra E. (2018). A Multilevel Analysis of What Matters in the Training of Pre-service Teacher's ICT Competencies. Computers \& Education, 122, 3242.

Türkiye İstatistik Kurumu (TÜIK). (2019). Hanehalkı Bilişim Teknolojileri Kullanım Araştırması. Access Address: http://www.tuik.gov.tr/Start.do Access Date: 23.09.2020. 
Işık, B., Özdemir, N., \& Kușlu, S. (2021). Bilgi ve iletișim teknolojilerindeki dönüşümler 1șığında öğretim elemanlarının dijital okuryazarlık durumlar1. Journal of Human Sciences, 18(3), 374-389. doi:10.14687/jhs.v18i3.6131

Ünal-Bozcan E. (2010). Eğitim Öğretim Faaliyetlerinde Teknoloji Kullanımı. Eğitim Teknolojileri Araştırmaları Dergisi, 1 (4), 1-13.

Üstündağ MT, Güneş E, Bahçivan E. (2017). Turkish Adaptation of Digital Literacy Scale and Investigating Pre-service Science Teachers' Digital Literacy. Journal of Education and Future, (12), 19-29.

Yapıcı Ü, Hevedanlı M, Akbayın H. (2010). Biyoloji Öğretmen Adaylarının İnternet Öz Yeterlik İnançlarının İncelenmesi (Dicle Üniversitesi Örneği). In IETC-International Educational Technology Conference, April 26, (Vol. 28, pp. 237-241).

Yılmaz M, Üredi L, Akbaşlı S. (2015). Sınıf Öğretmeni Adaylarının Bilgisayar Yeterlilik Düzeylerinin ve Eğitimde Teknoloji Kullanımına Yönelik Algılarının Belirlenmesi. International Journal of Humanities and Education, 1:1, 105-121.

Yılmaz, A., Kaya, M., Akca, N., Sönmez, S. (2019). Sağlık Bilimleri Fakültesi Öğrencilerinin Dijital Okuryazarlık Düzeylerinin İncelenmesi. 3rd International 3th National Congress on Health and Hospital Administration, (pp.287-297).

Yontar A. (2019). Öğretmen Adaylarının Dijital Okuryazarlık Düzeyleri. Ana Dili Eğitimi Dergisi, 7 (4), 815-824.

Yurtseven, N., Saraç, S., AKGÜN, E. (2021). www. ejer. com. tr. Eurasian Journal of Educational Research, 94, 295-314.

\section{Extended English Summary}

In parallel with globalization and the increase in knowledge production, rapid technological developments and transformations, institutions, professions and individuals, which have pushed all existing institutions and systems to an irresistible change process and have a great impact on the future of each country and society, especially at the end of the twentieth century.

In the early 2000s, the European Commission identified digital literacy as one of the lifelong learning competencies. The importance of lifelong learning and the acceleration of the development of information and communication technologies have increased the importance of digital literacy. It has become an inevitable necessity to change education systems and educator competencies in order to face the threats created by all these effects and transformation and to provide a better future for new generations in the globalizing and changing world. Universities have an important place in society in terms of production, protection, dissemination and implementation of knowledge. The adaptation of the community to new technological developments depends on the universities' use and development of digital technologies in the learning-teaching process. In the light of the above, this study has been planned in order to determine the digital literacy levels of lecturers and the factors affecting them in the light of the transformations in information and communication technologies and to create a source for related studies.

This cross-sectional and descriptive study was conducted in 2018 with 272 lecturers working at a state university. Personal Information Form and Digital Literacy Scale were used in data collection. Personal Information Form Prepared by Researchers; It consists of 16 questions such as gender, age, department, title, technologies used to connect to the internet, tools and equipment used in educational activities, having a website, how many hours a day and for what purposes. Digital Literacy Scale consists of five sub-dimensions and 41 questions. The individuals to be included in the study were informed within the scope of the research, and the data were collected through questionnaires by obtaining informed verbal and written consents from those who agreed to participate in the research process. Research data were analyzed in SPSS 22.0 package program. The data were analyzed using frequency, percentage, $t$ test, Kolmogorov Smirnov, Mann-Whitney $U$ and Kruskal Wallis test, and the results were evaluated at 95\% confidence interval and $\mathrm{p}<0.05$ significance level.

The results of the study showed that $90 \%$ of the academic staff participating in the research use mobile phones to connect to the internet, $90.4 \%$ use computers for educational 
Işık, B., Özdemir, N., \& Kuşlu, S. (2021). Bilgi ve iletişim teknolojilerindeki dönüşümler 1şığında öğretim elemanlarının dijital okuryazarlık durumlar1. Journal of Human Sciences, 18(3), 374-389. doi:10.14687/jhs.v18i3.6131

purposes, $89.7 \%$ use computers for educational purposes and $100 \%$ use the internet. In our study, it was determined that the digital literacy levels of lecturers in the 22-27 age group, lecturers and lecturers with 3-5 years of working time as instructors were much higher than other groups. It was determined that the total score average of the lecturers on the Digital Literacy Scale was $169.05 \pm$ 28.71. The mean score of the awareness sub-dimension was $71.51 \pm 11.91$; Contextual Usage subscale mean score was $38.57 \pm 6.94$; Safe Participation subscale mean score was $23.38 \pm 5.26$; The average score of the Digital Identity sub-dimension was $15.55 \pm 3.25$; The average score of the Basic Tool and Media Knowledge sub-dimension was determined as $19.37 \pm 4.37$. In addition, it was determined that male faculty members got higher scores than women in all sub-dimensions and the overall scale.

The results of the research show that the digital literacy levels of academic staff are very high, variables of age, gender, academic title and working year affect the digital literacy level and that instructors mostly use digital technologies in their educational activities. The digital literacy skill, which enables access to information in digital environments, uses information effectively, distinguishes correct and valid information, and produces new information, is considered an indispensable element for learning-teaching processes and teaching staff to acquire these skills. Being aware of innovations in the light of current information is very important for higher education. In this context, understanding that digital transformation affects all institutions and systems as well as universities, structuring digital activities in line with the university's mission and vision, and redefining education systems in the light of digital transformation are of key importance for higher education institutions. In line with these results; Organizing educational activities related to digital literacy skills in higher education institutions within the scope of continuing education activities, especially the participation of academic staff and women educators in digital literacy education, establishment of technical support units that will integrate technology with faculty members, the learning-teaching process and teaching staff, digital technologies in educational activities are correct and effective must be motivated to use it. 